Article

\title{
Techno-Economic Analysis of Grid-Connected PV and Fuel Cell Hybrid System Using Different PV Tracking Techniques
}

\author{
Saif Mubaarak ${ }^{1}$, Delong Zhang ${ }^{1}$, Yongcong Chen ${ }^{1}$, Jinxin Liu ${ }^{1}$, Longze Wang ${ }^{1}$, \\ Rongfang Yuan ${ }^{2}$, Jing $\mathrm{Wu}^{2}$, Yan Zhang ${ }^{2, *}$ and Meicheng $\mathrm{Li}^{1}{ }^{1}$ \\ 1 State Key Laboratory of Alternate Electrical Power System with Renewable Energy Sources, School of New \\ Energy, North China Electric Power University, Beijing 102206, China; 120174300057@ncepu.edu.cn (S.M.); \\ zhangdelong@ncepu.edu.cn (D.Z.); 120192211901@ncepu.edu.cn (Y.C.); 120192211823@ncepu.edu.cn (J.L.); \\ 1182111018@ncepu.edu.cn (L.W.); mcli@ncepu.edu.cn (M.L.) \\ 2 School of Economics and Management, North China Electric Power University, Beijing 102206, China; \\ 120192206505@ncepu.edu.cn (R.Y.); 120192206450@ncepu.edu.cn (J.W.) \\ * Correspondence: zhangyan8698@ncepu.edu.cn
}

Received: 22 October 2020; Accepted: 23 November 2020; Published: 28 November 2020

\begin{abstract}
Solar energy has attracted the attention of researchers around the world due to its advantages. However, photovoltaic (PV) panels still have not attained the desired efficiency and economic mature. PV tracking techniques can play a vital role in improving the performance of the PV system. The aim of this paper is to evaluate and compare the technical and economic performance of grid-connected hybrid energy systems including PV and fuel cells (FC) by applying major types of PV tracking technique. The topology and design principles and technical description of hybrid system components are proposed in this paper. Moreover, this paper also introduces economic criteria, which are used to evaluate the economy of different PV tracking techniques and seek the optimal configuration of system components. In the case study, the results show that the vertical single axis tracker was ranked 1st in terms of highest PV generation, penetration of renewable energy to the grid, lowest $\mathrm{CO}_{2}$ emission, highest energy sold to the grid and lowest purchased, and lowest net present cost (NPC) and levelized cost of energy (LCOE). The study found that the optimal design of a grid-connected hybrid energy system (PV-FC) was by using a vertical single axis tracker which has the lowest NPC, LCOE.
\end{abstract}

Keywords: optimal configuration; techno-economic analysis; PV tracking techniques; fuel cell; hybrid systems

\section{Introduction}

Climate warming and pollution are major concerns around the world due to reliance on fossil fuel for energy supply; $82 \%$ of the global energy supply using fossil fuel for electricity generation causes $40 \%$ of global carbon dioxide emissions. In addition, fossil fuel has the disadvantages of fluctuating prices, transportation difficulties, and finite resources. All these concerns push the world to seek for alternative energy sources that are environmentally friendly and renewable [1]. In this regard the development of renewable resources such as solar, wind, biomass, and hydropower attracts attention to overcome traditional fossil fuel challenges.

At the present time, renewable energy occupies $26 \%$ of global electricity based on reports of the international energy agency (IEA). In addition, the prospective rate will reach $30 \%$ by 2024 with a total installed capacity of $1200 \mathrm{GW}$, half of which came from solar energy. The IEA expects that solar energy will significantly dominate and can play a major role in jumpstarting the maturity of global renewable energy due to dropping costs and rapid development of photovoltaic (PV) technology, where the costs 
of solar energy are projected to decline by $15 \%$ to $35 \%$ by 2024 [2]. The utilization of solar energy is one of the most promising solutions for declining grid power usage and carbon dioxide emission.

However, solar energy has its challenges, namely, its intermittent nature and unreliability [3]. To address the first challenge, most of the studies have taken three different approaches. The first approach is integrated with multi-renewable energy sources such as wind or hydro energy for supplementing each other [4-10]. The second approach is the grid-connected PV system. Combining a PV system with grid power can complement each and deliver constant power to users [11-14]. The third approach is to develop the use of storage technologies integrated with a PV system in order to supply smooth power to demand.

Studies in [15-19] have revealed different types of storage technology that demonstrate great potential for smoothing the generation of renewable power. Among these different kinds of storage technology, batteries are usually integrated with renewable energy systems for electrifying stand-alone applications [20-22]. However, the battery storage technology has its limitations such as a short life cycle due to frequent charge and discharge, periodic maintenance that is difficult to undertake in isolated area, and possible environmental harm [23].

Another alternative option is the hydrogen storage system. This kind of energy storage technology has the advantages of long lifetime, high-density energy storage, environmental protection, and lower maintenance cost. Therefore, hydrogen energy storage is the best choice to integrate with renewable energy sources for standalone applications [24,25], where remote regions are difficult to reach. The combination of a renewable energy system and hydrogen energy storage needs an energy management strategy for scheduling energy from renewable sources to load when the load fully satisfies the excess energy transfer to the hydrogen system in order to produce hydrogen by an electrolyzer through the electrolysis of water to hydrogen and oxygen. A fuel cell (FC) uses hydrogen and oxygen to generate power at the fluctuation period of renewable sources [26].

The integration of PV and FCs has received great attention in recent years. A study by [27] was conducted with six different configurations of microgrid hybrid (PV/wind/battery/FC), and the improved bees algorithm was used to find the optimal design of the six configurations. It was found that hybrid renewable energy based on battery storage was more cost effective than hydrogen energy storage. The economic performance of the optimal design of hybrid PV-FC have been evaluated in [28] for electric load in the city of Brest, and the result clearly illustrated that the proposed system was the best alternative choice to a conventional diesel generator, non-polluting, and a reliable energy system with minimum cost of maintenance. An off-grid design hybrid (PV/FC) was optimized to meet residential electric load in an isolated region, and the effect of ambient temperature and dust accumulation of the PV system and design performance were examined. The optimized design was economically viable with $145 \$$ /MWh and environmental protection (no carbon dioxide emission) [29].

However, the hydrogen system (electrolyzer, tank, fuel cell) equipped with renewable energy sources still has drawbacks such as cost and efficiency. Reference [30] reported that the product of hydrogen from renewable energy sources has costs two to three times higher than that produced from natural gas. With continuous decline in the cost of solar and wind technology, pure hydrogen becomes more affordable in the future. To decrease the cost, development of the technology of the electrolysis of water into hydrogen was recommended. The significant issue facing fuel cells today is the cost. The fuel cell is not economically mature [31]. Furthermore, the challenge of a hydrogen system;s cost is the concern of [32], and considerable improvements are recommended for it to be highly competitive. For backup power at stationary applications, there is no specific efficiency goal, but the fuel cell efficiency directly expresses into the size and cost of both hydrogen storage and electrolyzer due to the fuel cell efficiency is negotiable with its size and its cost. Therefore, an optimization study is most important to determine the efficiency of fuel cell, resulting in up to $50 \%$ in achievable efficiency [33]. In this regard, most studies focused on optimization, sizing, and operations techniques of hybrid energy systems, and accordingly techno-economic performances were assessed. Among different topics in operation techniques, the PV tracking techniques have been considered. 
The literatures review is classified into two sections: studies regarding hybrid energy system whether microgrid or grid-connected and studies assessed the various PV tracking techniques.

\subsection{Studies Related to the Hybrid Energy Systems}

Techno-economic feasibility of a hybrid energy system was investigated for electrifying village load in Sarawak, Malaysia. The system included FC and excluded FC were assessed and compared with diesel generation. Homer software was used to optimize and analyze. The analysis was based on net present cost (NPC), and the cost of energy (COE). The result shows that the hybrid system (PV/batteries) was economically feasible with NPC of $\$ 3,335,297$ and the energy cost of $0.323 \$ / \mathrm{kWh}$ with no emission. It was a suitable choice for replacement of conventional diesel based system, whereas FC based system was higher cost and excluded as the best choice for a case study [34]. A flower pollination algorithm (FPA) was employed to optimize hybrid energy system, and compared with the particle swarm optimization (PSO) and the artificial bee colony $(\mathrm{ABC})$ techniques. The outcomes results shown that the FPA has less convergence time, and was better than the other two algorithms. Additionally, the losses power supply probability (LPSP) was $1.52 \%$ and the system NPC was $\$ 3,244,897$, with levelized cost of energy (LCOE) of $0.334 \$ / \mathrm{kWh}[35]$.

In [36] PSO showed a better result for optimization of grid-connected hybrid energy system (PV, solar thermal collector, FC) compared with genetic algorithm(GA). In the hybrid energy system (PV/Battery/FC), the hydrogen and fuel cell have been assessed and their potential verified for the telecom market. The result collected of full year has compared with diesel generator-based power system. The result illustrated that the integration of renewable energy solution was competitive regarding energy efficiency and reduced consumption of fossil fuel [37]. The colony selection algorithm (CSA) has been used for optimizing a hybrid energy system (PV/wind /FC), the results indicated that CSA was most cost-effective, and ensure reliable power supply with better LPSP. However, convergence time was longer compared with homer optimization [38].

In hybrid power system (PV/battery/FC/grid) [38], a demand response program (DRP) has been employed to achieve the best operation cost of the proposed system. The load was classified into off-peak, mid, and peak periods, and in each period the energy prices were different, export some amount of load from peak to other periods to reduce the cost. A thermal storage system is used to save energy in both off-peak and mid-period to supply load at peak hours. The result illustrated that using a demand response program has achieved the best cost effect of the system and minimized purchases power from the grid compared without used DRP [39].

A techno-economic study of hybrid energy system (PV/wind/battery/FC) has been conducted based on metrological data for different towns in Saudi Arabia. Six different configurations were studied. Homer pro was used to perform simulation and optimization. The study showed that the hybrid renewable energy sources with battery storage was most cost-effective, replacement battery with hydrogen storage system the cost increased because of the cost of electrolyzer, hydrogen tank, and fuel cell [40].

In addition, a hydrogen and battery storage system were powered by hybrid (PV/wind) for electrifying costal electric load in Izmir, Turkey. Homer pro was used to perform simulation, calculations, and optimization. The result illustrated that the LCOE of microgrid hybrid renewable energy sources was above the price of the energy unit of grid electricity. As well, battery storage has become a very mature technology, and is still economically dominant to hydrogen storage [41].

In the hybrid energy system (PV/wind/battery/FC), to minimize the cost cases of hydrogen energy storage were considered. The FC is considered as the secondary backup power supply to meet load deficit when the battery reached its minimum capacity. Homer is used to simulate and optimize the system. The result shows that the LCOE was more economical than previous study of hybrid power system (PV/wind/Genset) [42].

Despite the hydrogen storage and FC not being economically mature, if they are integrated and adequately sized, they can decline the overall cost of the system and prolong the lifetime of battery as 
well [43]. Study in [44] used a simulated annealing algorithm for sizing optimization of the hybrid system (PV/wind/ battery/FC) to provide an isolated area in Iran. Six configurations were examined to gain the best life cycle cost. The result found that the hybrid system (PV/wind/battery) has offered the best cost and reliable energy than the hybrid system with hydrogen energy storage. Among many hybrid energy systems, a wind/battery-based hybrid system was clearly merited economically of supply power.

All previous optimization techniques were lengthy, complicated in design, and provided inaccurate simulation results, whereas Homer's optimization algorithm accurately seeks for the optimal configuration design, and the sensitivity algorithm makes it simple to assist as the possible number of configuration's design. This demonstrates a highly feasibly simulation result than other optimization techniques [45]. On the other hand, efficient energy management can play a vital role for ensuring the delivery of smooth power to demand through high capability to handle describe variations of renewable energy sources. In this context, studies in [46-48] demonstrate great power management scheduling among integrated power sources.

\subsection{Studies Related to Photovoltaic (PV) Tracking Techniques}

Dual-axis sun tracker showed $44.7 \%$ performances compared better with fixed-tilt solar panels for the PV system in Perlis, Malaysia [49]. The performances of static-axis solar panels and single axis-solar tracker of hot climate equator region in Mossoro city, Brazil, are compared. The study deduced that the panels used single-axis sun tracker showed noticeability average power gain compared to the static-title panels. This was due to the location approximate in the equator area; there was no large difference in sun path during day or year. Therefore, the density of solar radiation received is still high [50].

The study in [51] found that an equatorial tracker parallel with the earth's axis, and elevation rolling by an east-west direction tracker are superior to azimuth elevation by the vertical direction tracker, and rolling elevation by a north-south direction tracker. The case was a PV system in Arguedas (42.1 North and 1.58 West).

Feasibility study of sun-tracking technology for PV panels in cold and hot climate is compared. The study found that in the cold climate like Berlin, Germany. The gain in power was 39\%. The gain in power has not excessed $8 \%$ in the case of a hot climate like Aswan, Egypt. Therefore, if the power needs to drive sun tracker in the range from $5 \%$ to $10 \%$, meanwhile, sun-tracking technology is not feasible in hot countries [52].

The study in [53] proposed a PV tracking method based on the second derivative of energy produced and compared it outcome performances with PV tracker continuously follow the sun path, and PV tracker with step time following the sun. The result found that a PV tracker based on derivative of energy could be higher $2 \%$ of energy production than of the step time PV tracker.

A new design dual-axis tracker was implemented for PV panels at a latitude close to $30^{\circ}$. This tracker system costs $27 \%$ less than the conventional PV tracking technology. The result demonstrated that this system raised the collection efficiency by $24 \%$ related to a fixed device [54]. Two low cost PV power system have been installed in high and low altitude sites in the south of Australia. A dual PV tracker was considered for following the sun. The result showed that the higher gain of PV out yield in the higher altitude test, it amounts approximately $5 \%$ increase of peak power in high altitude [55].

The study in [56] assessed the techno-economic role of a sun tracking system of a standalone hybrid PV-pump storage hydroelectric (PV-PSH) energy system, for supplying the Costal area, south of Iran. The potential of PV tracking technology such as horizontal, fixed title, east-west horizontal axis tracker, azimuth vertical axis tracker, and dual-axis tracker was examined. The result demonstrated that the azimuth vertical axis tracker led to the minimum investment cost in the system, and good matching between demand and supply. As well, up to $18.2 \%$ of electricity could be saved. 
The study in [57] has investigated the potential of $31^{\circ}$ existing fixed tilt, $29.25^{\circ}$ yearly optimal tilt, as well six-PV tracking technology for the purpose determine the optimal configuration of a hybrid standalone system (PV-wind-battery) in low windy and good solar in hilly terrain, India. Homer software is used to develop the design. The result found that the optimal configuration of all sun-tracker except dual-axis tracker was $7 \mathrm{kWp} P V, 5 \mathrm{kWp}$ wind turbine, 10 batteries, and $2 \mathrm{kwp}$ inverter. Moreover, for the dual-axis tracker and two-fixed title the optimal configuration was $8 \mathrm{kWp} \mathrm{PV}, 5 \mathrm{kWp}$ wind turbine, 10 batteries, and $2 \mathrm{kWp}$ inverter. The result showed that horizontal axis (monthly, daily, continuous adjustment), and a dual-axis tracker generated 4.88-26.29\% extra energy each year than of the existing fixed tilt. The cost of energy was found to be more in terms of a dual axis tracker than other PV trackers and two-fixed tilt.

In [58] techno-economic optimization of the hybrid energy system (PV/battery) for powered rural healthcare building, in south India is studied. Fixed tilt, annual optimal tilt (AOT), and six sun-tracking techniques were investigated using Homer software. The objective function wanted to arrive at the lowest investment cost, represented by NPC, LCOE. The result indicated that AOT with fixed installation could be achieved optimum configuration and attain an objective goal.

Different major types of PV tracking system were reviewed in the study [59]. In this review, the study confirmed that the azimuth and dual-axis tracker were more efficient than other solar tracking technology. However, in terms of flexibility and economics, the single-axis tracker was more feasible than two-axis tracker. An off-grid hybrid energy system (PV/battery/Diesel) is compared with excluded diesel from the hybrid system, for supplying households in Urumqi. The fixed title, one-axis tracker, and two-axis tracker were examined their effect on technical and economic factors of the system. The result demonstrated that the PV system produced approximately $3.68 \mathrm{MWh}, 3.79 \mathrm{MWh}$, and 3.83 MWh, for the fixed title, one-axis tracker, and two-axis tracker, respectively. The hybrid power system (PV/battery/diesel) was economically superior, whereas, the diesel-based power system was more expensive. The greenhouse gas emissions (GHG) reduced $5.5 \mathrm{t}, 5.6 \mathrm{t}$ for fixed-tilt, single or two-axis tracker. The off-grid hybrid energy system (PV/battery) with a single or two-axis tracker could demonstrate better performance regarding GHG reduction [60].

The PV tracking technology has been considered for the grid-connected PV system in Makkah, Saudi Arabia. The fixed-tilt, horizontal-axis (continuous, daily, weekly, and monthly adjustment), vertical continuous adjustment, and dual-axis tracker were examined. The result indicated that, in the dual-axis tracker, vertical-axis continuous adjustment gained up of $35 \%, 20 \%$, more power than the fixed-tilt system, respectively. In addition, the horizontal adjustment shows the highest NPC, and LCOE. The study recommended that the vertical continuous adjustment was the best choice, as it achieved the best NPC, LCOE. Also, high solar energy penetration to the grid [14].

Three major PV trackers, fixed-tilt, one-axis trackers, and two-axis trackers were examined for a grid-connected PV system. A result of analysis indicated that implementation of dual-axis tracker could gain $35 \%$ more output power compared to static axis solar panels. Moreover, the project also reduced $\mathrm{CO}_{2}$ emission by $606 \mathrm{t}$ [61]. A $10 \mathrm{MW}$ PV power plant in Al-Anbar, Iraq has been assessed under effect of three major PV tracker namely: fixed-tilt, single-axis tracker and two-axis tracker. The study aimed to evaluate the project from an economic and environmental perspective. The result illustrated that the two-axis tracker could enhance the economic feasibility of the project. Also, the reduction of GHG emissions was ensured [62]. Fixed and dual-axis tracking PV system has been installed in the US upper Midwest. The cost of energy produced by the fixed and dual-axis tracker were calculated to be $\$ 0.31$ and $\$ 0.37$ for each $\mathrm{kWh}[63]$.

In conclusion, the different PV trackers have different advantages and disadvantages. For tracking the solar energy and generating power, the dual-axis tracker is the best choice owing to its ability tracking the sun at different angles. However, it has extra investment cost on the tracking system. The fixed-tilt solar panel is the cheapest, but it has the worst ability of harvesting solar energy. For the horizontal single-axis tracker (HSAT) and the vertical single-axis tracker (VSAT), their costs and abilities of harvesting solar energy are similar. Furthermore, for the NPC, LCOE and GHG, the common 
conclusions cannot be got because the conditions, such as weather, geographic position and load demand, are different.

\subsection{Contributions of Our Study}

In view of the current research status, several studies have pointed out the technical and economic analysis of various PV tracking technologies. However, most of the studies only focus on the PV system as an independent power system, such as [49-55]. In addition, few researchers put forward its application in a hybrid or integrated system. At present, there is no research report on a hybrid or integrated energy system (PV-FC). The significance and contribution of this study are summarized as follows:

(1) Based on the authors' understanding, the influence of PV tracking technology on the technical and economic performance of grid connected hybrid energy system (PV-FC) is studied for the first time. The research of a hybrid energy system (PV-FC) is more meaningful in a real application.

(2) In our study, many technical and economic factors, such as PV power generation, excess energy, renewable energy penetration, GHG emissions, power purchased from the grid, power sold to the grid, lifetime project cost and LCOE and so on, are considered. Unlike other studies in [14,61-63], decision variables considered in their model are less so that the feasibility in other applications is poor.

(3) As described in the literature review [27-34], hydrogen energy system equipment still faces challenges, such as efficiency and cost. Therefore, in our study, it is considered to assist PV and the grid to meet critical load demand, which makes the hybrid system more economical.

\section{Hybrid System and Techno-Economic Analysis Method}

\subsection{Topology and Design Principle of Grid-Connected PV and Fuel Cell (FC) Hybrid System}

This section mainly discusses the design and operation principle of the system considered, Figure 1 Presents the schematic diagram of the designed system. The designed system is composed of two parts, the first part is the hybrid power system including PV and FC, and the second part is the power generation based on the grid. The major component of the hybrid power system are PV models, electrolyzer, hydrogen tank, fuel cell, dispatch energy management, and inverter. The real load data, solar irradiation, ambient temperature are considered.

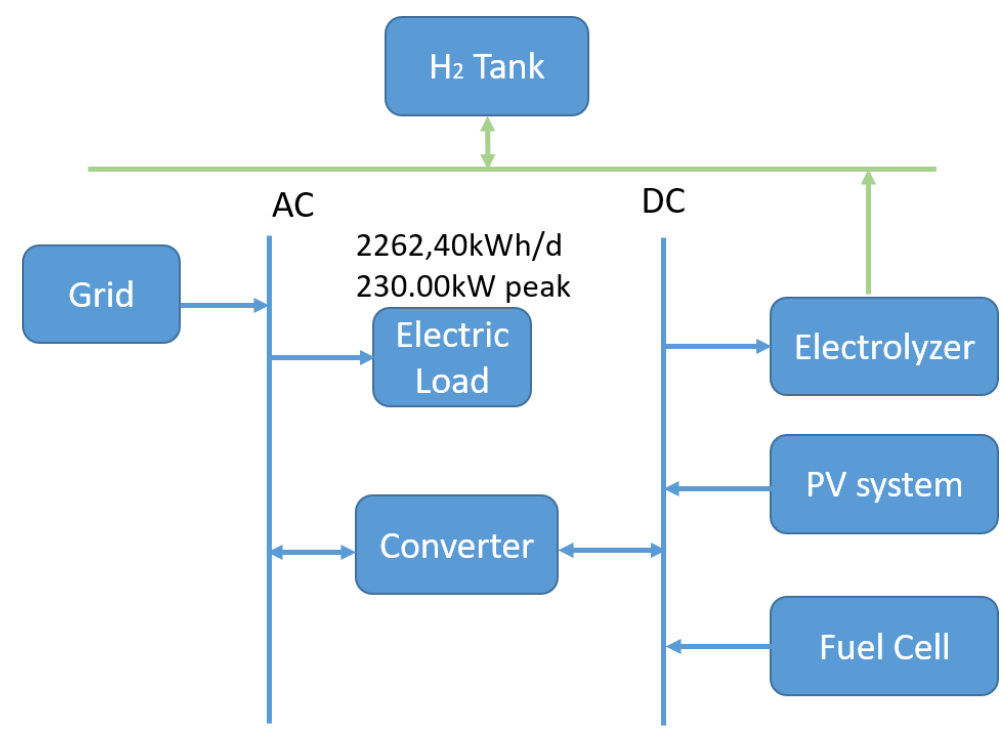

Figure 1. Schematic diagram of the grid-connected hybrid system (photovoltaic-fuel cell, PV-FC). 
In addition, the technical and economic characteristics of the components are identified. The maximum capacity shortage is considered as $0 \%$, and $50 \%$ minimum fraction of renewable energy. The system is designed to meet the load power requirement of $2262.4 \mathrm{kWh} /$ day and $230 \mathrm{~kW}$ peak load occurring in June.

The grid, PV, and FC are the major power supply contributed as follows: the grid is main power source at once solar radiation is not available specifically at night or early morning. FC is back up power to assist the grid when the load power requirement is not satisfied by power from the grid. PV is a daylight power supply to load and provide excess power to the electrolyzer for hydrogen production, even sell back to the grid if it is more than the demand of hydrogen production.

The hydrogen released by the electrolyzer is used to produce power in FC. A direct current to alternating current (DC-AC) converter is the interconnection between hybrid direct current (DC) system (PV-FC) and grid-connected system. It is used to convert the DC power produced by PV, FC section into alternative current $(\mathrm{AC})$ and accommodate it in the $\mathrm{AC}$ bus bar where the AC load is connected.

PV tracking techniques and their influence on techno-economic factors in the proposed system are examined. We use Homer to undertake simulation, calculation, and optimization of the designed system for different PV tracking techniques separately. In addition, this paper also seeks for optimizing the system sizing. The optimal design grid-connected (PV-FC) which reflected optimal techno-economic characteristic is recommended. The technical and economic characteristics of the system design components are applied in the below section.

\subsection{The Design of Hybrid System Components}

\subsubsection{Solar PV Models}

PV technology is a renewable power supplier based on solar irradiation, which produced DC electricity to the DC bus bar. In this study, the size of the PV model depends on system constraints such as the minimum fraction of renewable energy considered, maximum capacity of grid sold back, the density of solar irradiation, and load required. The PV models should be sized to be able to deliver power to peak load and provide excess power to the hydrogen system, for selling power back to the grid. In Homer, the formula presented the PV output power is illustrated in Equation (1) [64],

$$
P_{P V}=\gamma_{P V} f_{P V}\left(\frac{G_{T}}{G_{T, S T C}}\right)\left[1+\propto_{P}\left(T_{C}-T_{C, S T C}\right)\right]
$$

where, $P_{P V}$ is the output power from $P V$ array in $(\mathrm{kW}), \gamma_{P V}$ is the capacity of $P V$ array in $(\mathrm{kW}) . f_{P V}$ is the derating factor in (\%). $G_{T}$ the instantaneous solar irradiation in $\left(\mathrm{kW} / \mathrm{m}^{2}\right) . G_{T, S T C}$ is the solar irradiation at the standard condition and it is $1 \mathrm{~kW} / \mathrm{m}^{2} . \propto_{P}$ is the temperature coefficient of power $\left(\% /{ }^{\circ} \mathrm{C}\right) . T_{C}$ is the nominal operation of cell temperature in current time step in $\left({ }^{\circ} \mathrm{C}\right)$, and $T_{C, S T C}$ is the cell temperature at standard condition $25^{\circ} \mathrm{C}$. From Equation (1), it can be seen that various vectors can affect power produced from PV models, includes solar irradiation and ambient temperature. The technical and economic characteristics of PV models in our proposed system come from the manufacturer [65]. According to the manufacturer's datasheet, the lifetime of models is 25 years, model efficiency is $17 \%$, the derating factor is $90 \%$, and ground reflectance is $20 \%$. As the temperature effect on PV model power generation, the nominal operation of cell temperature is taken $45^{\circ} \mathrm{C}$, and the temperature coefficient on power is $-0.41 \% /{ }^{\circ} \mathrm{C}$. The economic cost of models is $1200 \$ / \mathrm{kW}$. $30 \$ /$ year for capital cost and operation and maintenance $(\mathrm{O}$ and $\mathrm{M})$ cost, respectively. In addition, replacement cost is considered as zero due to the long life of PV models.

\subsubsection{PV Tracking Techniques}

PV tracking techniques are the mechanism to adjust solar panels toward sun's rays for improving productivity and efficiency of the PV system through maximum utilization of solar irradiation. Commonly the fixed-tilt solar panel uses manually adjustable panel slops, and the advantages of 
this kind of PV installation is simplicity and low cost. However, they have a significant shortage to utilize the maximum possible of solar irradiation since the sun changes position throughout a day or a seasonal orbit [14]. PV tracking techniques can make a PV array automatically flexible to adapt toward high-density rays from the sun. Whether single-axis or two-axis tracker, the PV tracker needs additional components and accessories such as, motor, gear, control unit, and sensor that will increase the cost of the PV system [57]. The major four PV tracking techniques used in this study are:

- Fixed-tilt solar panel (FTSP).

- $\quad$ PV array is set fixed-tilt angle and azimuth. This is the commonest and simplest technique.

- Horizontal single-axis tracker (HSAT).

- The PV array is installed to rotate around the horizontal (east-west) axis. The tilt angle adjusts continuously for matching the angle of incidence, while azimuth is fixed.

- Vertical single-axis tracker (VSAT).

- PV array is installed to rotate around the vertical (north-south) axis. The tilt angle is fixed, while azimuth is adjusted simultaneously for matching the angle of incidence.

- Dual-axis tracker (DAT).

PV array is installed to rotate in both horizontal and vertical. Therefore, the incidence angle is always perpendicular to the surface of the panels.

The economic cost of horizontal, vertical and dual-axis tracker are stated in Table 1, and the four PV tracking techniques are presented in Figure 2 [56].

Table 1. The economic cost of different PV tracking techniques [14].

\begin{tabular}{cc}
\hline PV Tracking System & $\mathbf{\$} / \mathbf{k W h}$ \\
\hline Horizontal single axis tracker (HSAT) & 880 \\
Vertical single axis tracker (VSAT) & 265 \\
Dual axis tracker (DAT) & 1000 \\
\hline
\end{tabular}

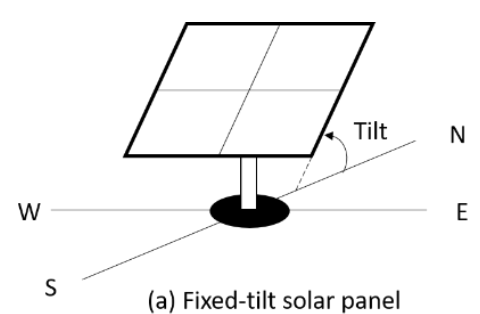

(a) Fixed-tilt solar panel

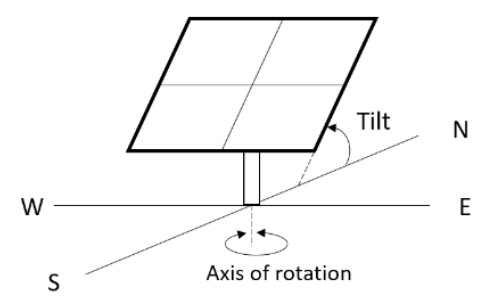

(c) Vertical single- axis tracker

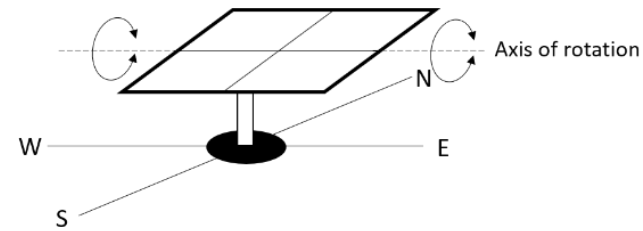

(b) Horizontal single-axis tracker

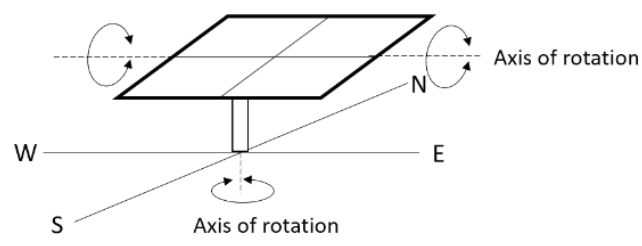

(d) Dual-axis tracker

Figure 2. Schematic diagram of major four PV tracking techniques [56].

\subsubsection{Electrolyzer}

An electrolyzer is an electrochemical device used to split water into hydrogen and oxygen through the electrolysis process. The power required for the electrolysis process comes from the excess power of renewable energy sources. The quantity of released gases depends on electrolyzer capacity and the amount of current passed through electrolyzer's cells [66]. The alkaline electrolyzer is selected to undertake this process due to its wide utilization and low cost among other electrolyzer technology [67]. 
The search space sizes of electrolyzer is considered in range 0-1400 kW, Homer seeks of optimal size in this range. The economic specification is addressed $1500 \$ / \mathrm{kW}$ capital cost, $1000 \$ / \mathrm{kW}$ replacement cost, and $20 \$$ /year $\mathrm{O}$ and $\mathrm{M}$ cost. The life cycle 15 year is considered, and 85\% operation efficiency [34].

\subsubsection{Hydrogen Tank}

The hydrogen generated from electrolyzer needs to be stored in the tank to be used by FC. The tank capacity is considered in search space range $0-1200 \mathrm{~kg}$, and the lifetime of the tank is considered 25 years. The economic tank specifications is considered $1400 \$ / \mathrm{kg}, 867 \$ / \mathrm{kg}$, and $20 \$ /$ year for capital, replacement, and $\mathrm{O}$ and $\mathrm{M}$ cost, respectively [42].

\subsubsection{Fuel Cell}

A hydrogen FC is an electrochemical-based power generation system. It combines hydrogen with oxygen to generate the electricity through chemical reaction. There are several kinds of FC technology. In this study, a proton exchange membrane (PEM) FC is used due to essential simplicity and executive reaction with low temperature. The electrolyte is a solid polymer and platinum is the catalyst. The protons are mobile through the polymer to the cathode, while electrons are transferred through the electrode to external load [66]. The FC is fed by hydrogen stored in a tank and oxygen from the air. The capacity of the FC is considered $100 \mathrm{~kW}$. Technical and economic specification is considered $3000 \$ / \mathrm{kW}$ capital cost, $2500 \$ / \mathrm{kW}$ replacement cost, $0.03 \$ / \mathrm{hr} O$ and M cost [42]. The life cycle is considered 40,000 h. The efficiency curve is shown in Figure 3, where the intercept coefficient is $0.0003 \mathrm{~kg} / \mathrm{hr} / \mathrm{kW}$, and the curve's slop is $0.21 \mathrm{~kg} / \mathrm{hr} / \mathrm{kW}$.

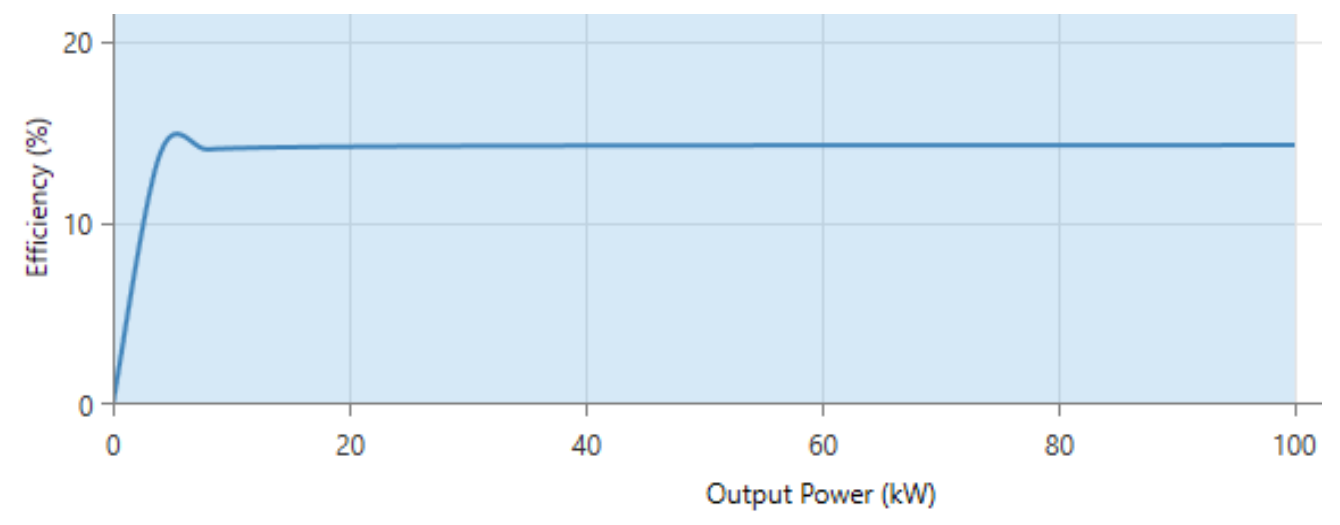

Figure 3. Efficiency curve of FC.

\subsubsection{Inverter}

DC provided from a PV-FC based hybrid power system needs to be converted into AC to be served as AC load. The DC-AC converter is used, and the inverter's optimized sizing is performed by Homer optimization process based on power flow from PV-FC section. The inverter efficiency is considered as 90\%, technical and economic data come from the manufacturer [68], where $250 \$ / \mathrm{kW}$ capital cost, $150 \$ / \mathrm{kW}$ replacement cost, and $10 \$ /$ year O and M cost. The life cycle is considered as 15 years.

\subsubsection{Grid}

The grid is the main power provider, whereas FC is the backup power supply used for assisting the grid when the load demand is higher than the range of grid purchased capacity. The PV is fed the load at daylight and provided excess power to be used for hydrogen system, or sold back to the grid. The renewable energy feed in tariff (REFIT) is the strategic contract with renewable energy suppliers for the cost of selling back energy to the grid. This contract varies from country to other, and relying on the policies that can accelerate to develop renewable energy to improve the penetration 
in grid power. In 2017, Saudi Arabia updated its REFIT to a new price that aimed to encourage to develop renewable energy and minimize the consume oil, gas for electricity generation. It changed the consumption rate to two categories from 1 to $6000 \mathrm{kWh}$, and more than $6000 \mathrm{kWh}$, corresponding to a new grid charge rate of $0.048 / \mathrm{kWh}$ and $0.080 \$ / \mathrm{kWh}$, respectively [64]. In addition, it defined a new grid schedule rate as shown in Figure 4, the figure shows a grid schedule rate through hours of day for all month, where the rows represent the hourly day started from 00:00 to 23:00. The rate included off-peak, shoulder, and peak time. Corresponding sell back charge rates are $0.0380 \$ / \mathrm{kWh}$, $0.0400 \$ / \mathrm{kWh}$, and $0.0700 \$ / \mathrm{kWh}$, respectively as illustrated in Table 2 .

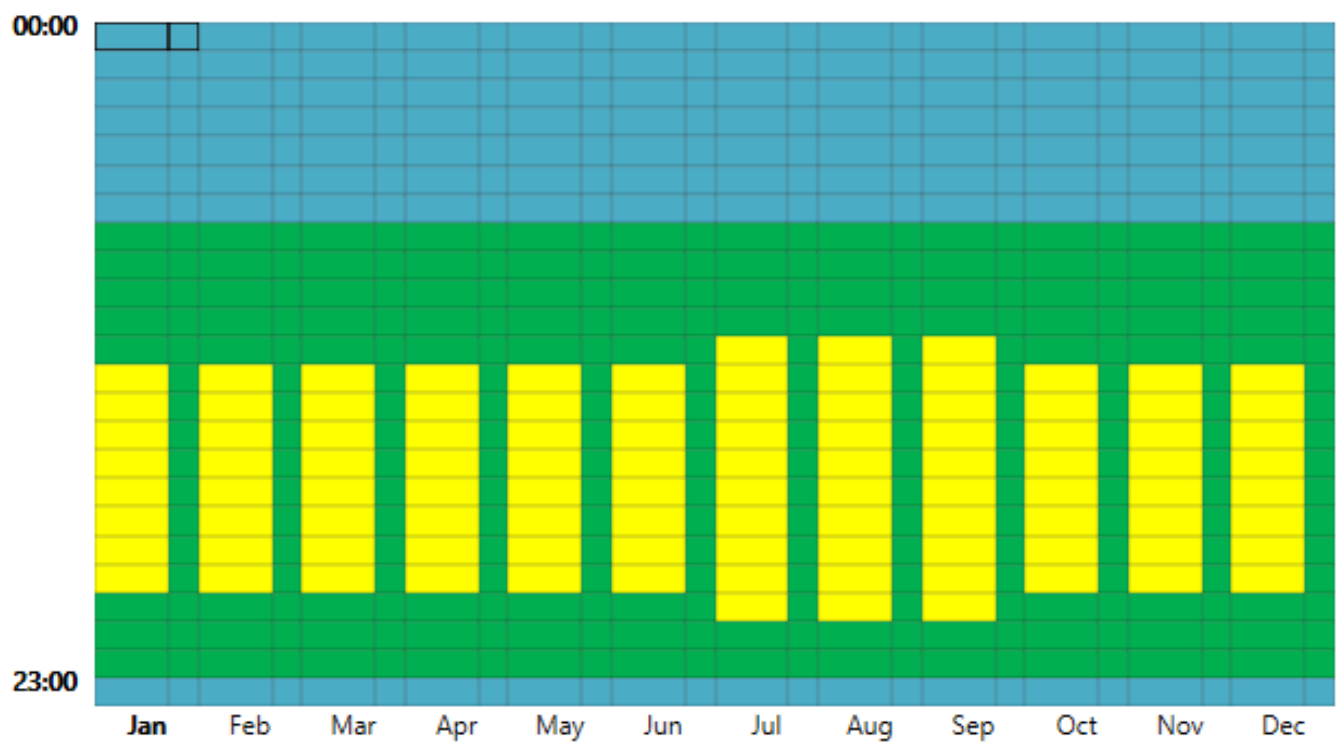

Figure 4. Hourly data-grid schedule rate for all months.

Table 2. Charge of grid schedule rate during the day.

\begin{tabular}{cccc}
\hline Period & Color & Price $\mathbf{( \$ \mathbf { k W h } )}$ & Sellback $\mathbf{( \$ \mathbf { k W h } )}$ \\
\hline Off-Peak & Wathet blue & 0.0480 & 0.0380 \\
\hline Shoulder & Green & 0.0480 & 0.0400 \\
\hline Peak & Yellow & 0.0800 & 0.0700 \\
\hline
\end{tabular}

\subsection{Economic Analysis Criteria}

The economic comparison between various proposed designs is carried out based on NPC and LCOE. Homer is used to calculate the NPC that represents the present cost minus the salvage as well as the revenue generated from selling power to the grid. Here, the present cost includes capital cost, replacement cost, and $\mathrm{O}$ and $\mathrm{M}$ of the whole system over the project life cycle. The salvage is the remaining value of components at the end of the investment. It can be estimated by Equation (2) [69].

$$
N P C=\frac{C_{a n n, t o t}}{C R F(i, N)}
$$

where $C_{a n n, t o t}$ is the annualized total cost of the entire system (\$/year). $C R F$ is the capital recovery factor. $N$ is the life cycle of the project. $i$ is the annual real interest rate, it can be estimated by the following formula [34]:

$$
i=\frac{i^{\mathrm{o}}-f}{1-f}
$$

where $i^{\mathrm{o}}$ is the nominal interest rate, which is the rate you can borrow money in (\%). $f$ is the annual inflation rate, which is the inflation rate expected through the project lifetime in (\%). Here in our case 
study 3\% is the nominal interest rate (discount) for Saudi Arabia in 2019 [70], while the inflation rate for the same year is $-0.7 \%$ [71]. Equation (3) shows the real interest rate is found at $3.7 \%$. The project lifetime is considered 25 years. The capital recovery factor can be calculated given by [69] as follows:

$$
\operatorname{CRF}(i, N)=\frac{i(1+i)^{\mathrm{N}}}{(1+i)^{\mathrm{N}}-1}
$$

The levelized cost of energy (LCOE) is the average cost of energy unit (kWh). Homer can calculate it by the divided total annual cost of the entire system in one year to the total energy generated through this year. It can be expressed by Equation [14] as follows:

$$
\operatorname{LCOE}\left(\frac{\$}{\mathrm{kWh}}\right)=\frac{C_{\text {ann,tot }}}{R_{\text {prim }}+R_{\text {tot,grid.sales }}}
$$

where $R_{\text {prim }}$ is the primary served load ( $\mathrm{kWh} /$ year), $R_{\text {tot,grid.sales }}$ is the total grid sold power per year(kWh/year). The annual total cost included all kinds of expenses, such as annualized capital, replacement, $\mathrm{O}$ and $\mathrm{M}$ cost.

\subsection{Energy Dispatch Principle of the Hybrid System}

The load following strategy is considered for dispatching energy. In this strategy, the fuel cell only operates to meet critical load demand, which PV and grid cannot meet. The backup power from the fuel cell does not handle electrolyzer. The power needed for feed electrolyzer is supplied by excess PV power. Furthermore, the PV power will be sold to the grid when it greater than the demand for hydrogen production. The dispatched energy for the following load is widely used due to the benefit such as reduce fuel consumption belonged to lower generator size [72]. This strategy has advantages in terms of of environmental aspects, and curtailment generator size in hybrid renewable energy/distributed generation (DG), which allows the generator to run for meet critical load but not further tasks such as supply batteries or electrolyzer [73].

\section{Introduction of Input Data and Software}

\subsection{Geographic Characteristic}

Alkharj town allocated at $24.145536^{\circ} \mathrm{N}, 47.311947^{\circ} \mathrm{E}$ in central Saudi Arabia is the case considered in this study. It is $77 \mathrm{~km}$ east of Riyadh, the national capital [74], as shown in Figure 5. Alkharj was selected as the location of the government experimental farm since 1938. Therefore, it has flourished agricultural oasis, cultivating different kinds of planets such as cereals, vegetables, dates, and fruits. In addition, other economic activities such as livestock, horse breeding, and poultry raising.

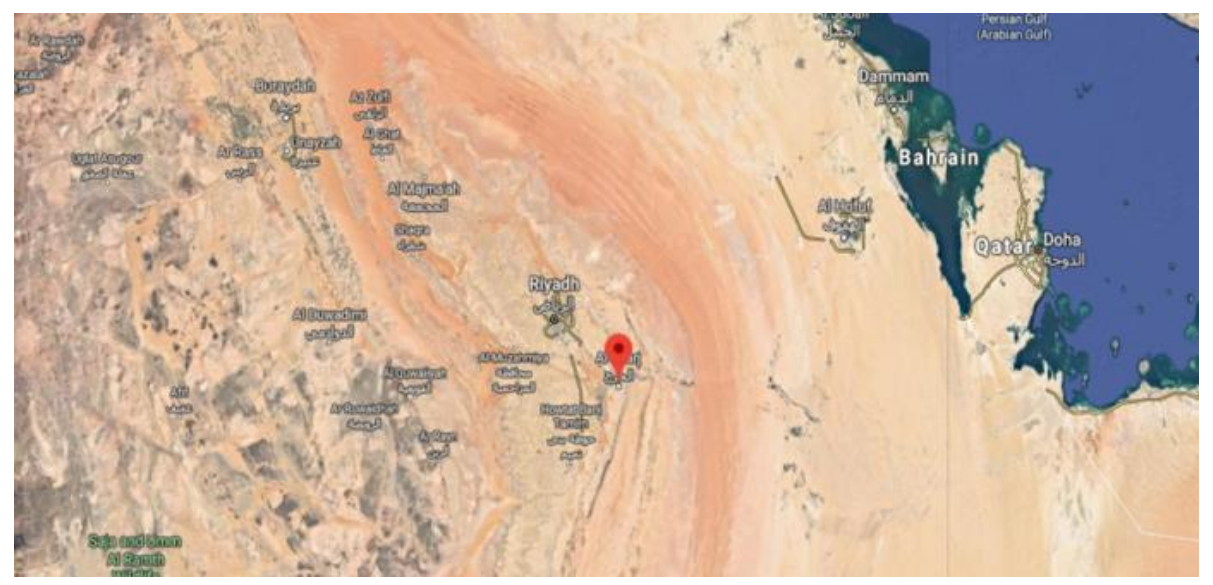

Figure 5. Alkharj town located in Saudi Arabia [64]. 


\subsection{Renewable Sources Assessment}

Solar irradiation and ambient temperature are unstable variables and, accordingly, the power of PV system is unstable. We use Homer to find the latitude and longitude of the site under study and access to National Aeronautics and Space Administration (NASA) surface meteorology and solar energy database for downloading solar irradiation and ambient temperature [75]. The monthly averages of these two meteorological data are defined in Homer resource inputs. The following two points provide more detailed analysis of these variables.

- The solar irradiation:

The monthly average solar irradiation is in the range from $3.51 \mathrm{kWh} / \mathrm{m}^{2} /$ day to $7.89 \mathrm{kWh} / \mathrm{m}^{2} / \mathrm{day}$, with the annual average of $5.8 \mathrm{kWh} / \mathrm{m}^{2} /$ day as shown in Figure 6 . The global horizontal irradiance (GHI) is risen above the average value in the months from April to September with the peak value recorded in June. The remaining months are shown relatively lower than the average value of solar irradiation with the lowest average value recorded in December.

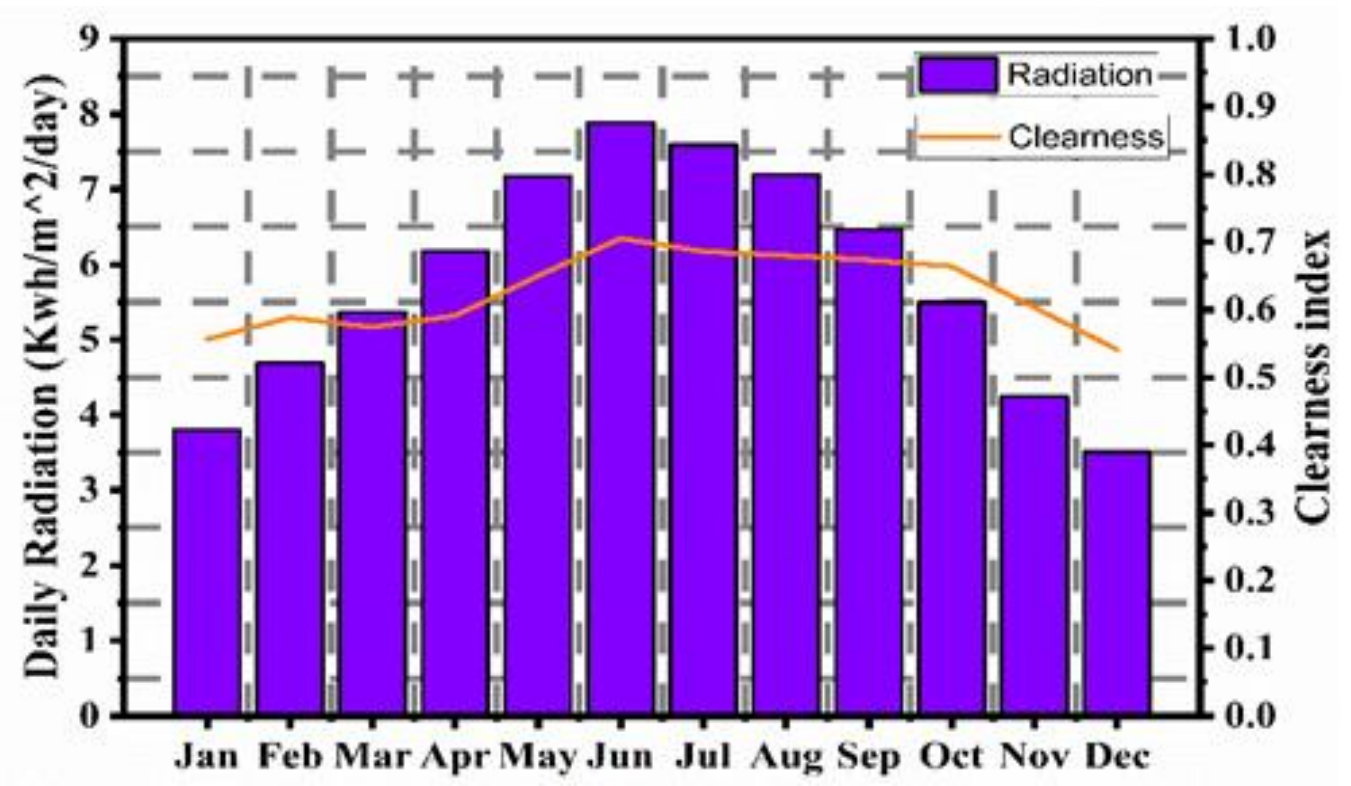

Figure 6. The monthly average solar global horizontal irradiance (GHI), clearness index in Alkharj.

- The ambient temperature:

The air temperature of the considered site is taken in to account. It significantly affects the output characteristics of the PV system. The monthly average air temperature is depicted in Figure 7 , which ranges from $15.12{ }^{\circ} \mathrm{C}$ to $36.2{ }^{\circ} \mathrm{C}$ with an annual average of $26.85^{\circ} \mathrm{C}$. The ambient temperature is higher than the average value in the month from April-October, and is recorded highest in July. The remaining months are shown low average value with the lowest average value appeared in January. 


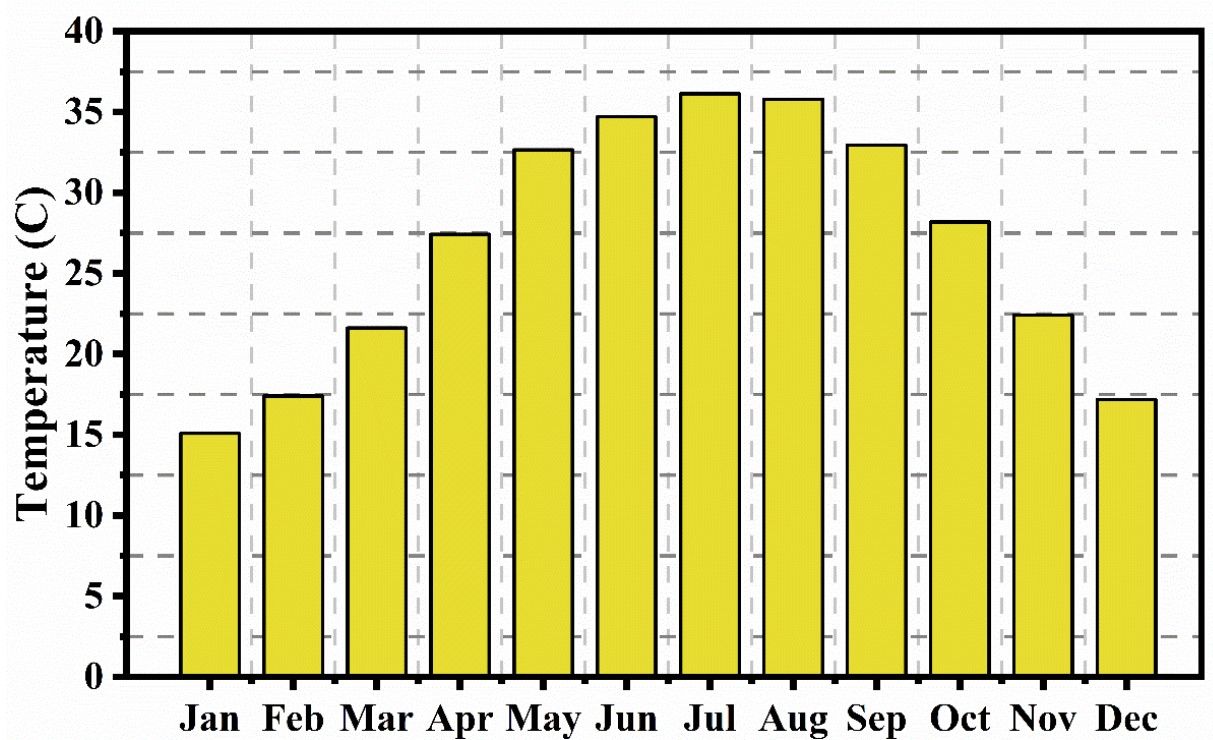

Figure 7. The monthly average ambient temperature in Alkharj.

\subsection{Load Data}

The electric load is the end of electric system consumption that the power suppliers need to draw it. Load estimation is the most significant thing for the optimal design of any electric system and avoiding over design that raises the system cost or under design that causes blackout [14]. Alkharj region is one of the richest water resources in Saudi Arabia that has support agriculture activities, the area is included several agricultural farms such as: grains, wheat, barley, vegetables, poultry, dairy, dates farms [76]. In this paper, the agriculture load is considered for analysis [77]. The load profile is depicted in Figure 8, which shows high electricity consumption in the months from April to September. This is mainly due to the abundance of irrigation activities in the summer, where the weather encourages the cultivation of most plants such as crops, and vegetables. The maximum load demand is recorded as $230 \mathrm{~kW}$ in June. The monthly average load demand is illustrated in Figure 9. The daily average energy consumption is $2262.4 \mathrm{kWh} /$ day.
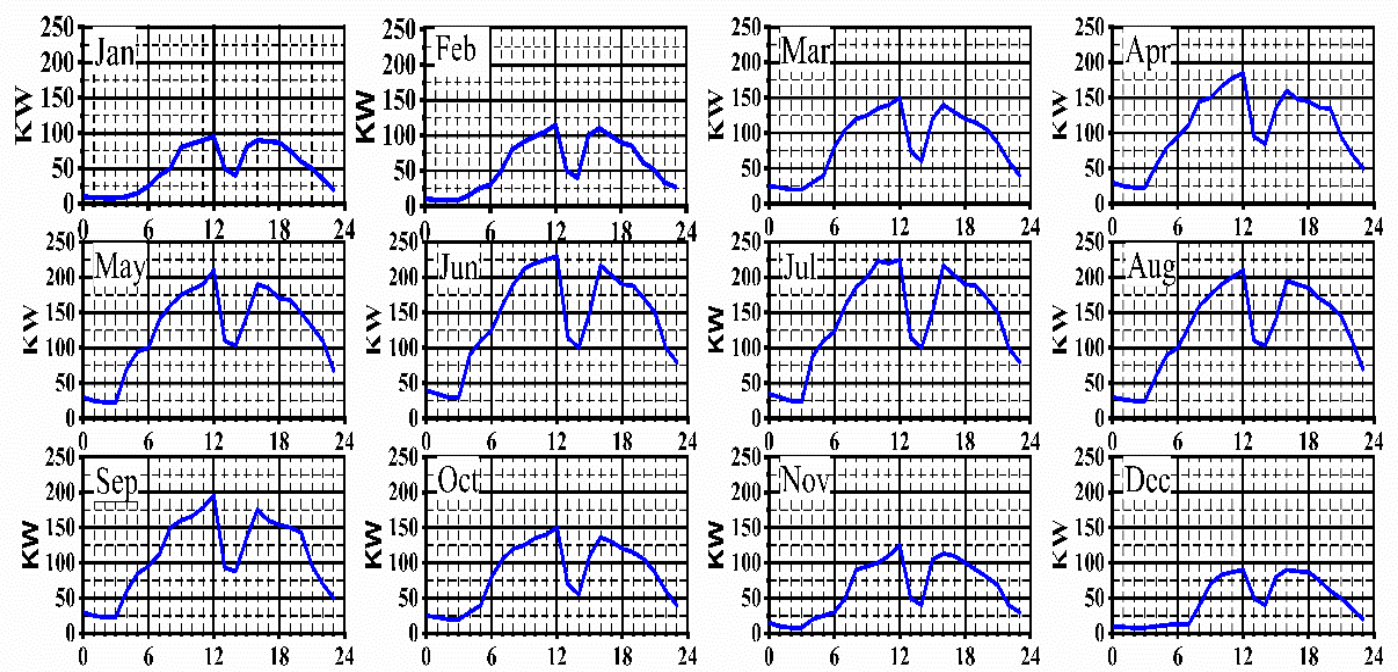

Figure 8. Scaled data daily profile of the load for all months. 


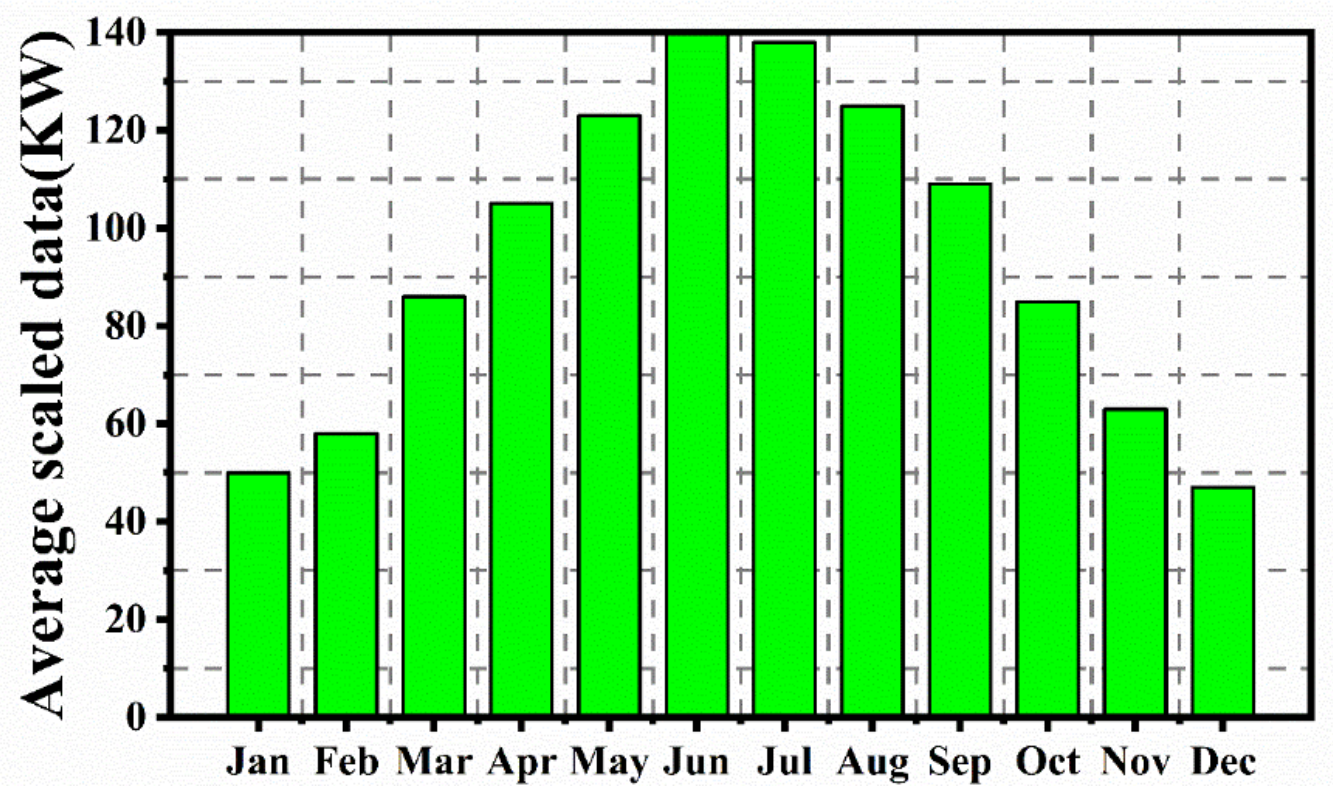

Figure 9. Scaled data monthly averages of the load.

\subsection{Homer Pro Software}

Comprehensive simulation tools could implement techno-economic evaluation of the power system, as an alternative to the complicated and lengthy algorithms and costly laboratory experiments. There exist different softwares for design, simulate, and optimization renewable energy systems, primarily for assess techno-economic aspects. HOMER, iHOGA, PVSyst, Hybrid2, RETScreen, and TRNSYS are among the most frequently used as pointed out in literature.

Homer is superior on others due to it has capability to handle various power system configurations, develop design, simulate, and perform optimization. Furthermore, it can undertake sensitivity analysis, demonstrate detail explanation of economic aspects, and system operation [14]. In addition, it is friendly to the user and presents powerful graphics. Homer is an abbreviation for hybrid optimization of multiple electric renewable which is developed by national renewable energy laboratory in United States for designing, simulating and optimizing integrated power systems. It includes a mix of conventional generators, combined renewable energy sources.

Homer is used currently by thousands of researchers around the world for simulation of power systems either off-grid or grid-connected. Homer helps to determine the economic feasibility of the integrated power system through optimizes the design and seeks for the optimal configuration [78]. To simulate any power system, users need to define meteorological climate, load data, elements technology in Homer which are required to design systems; for example, searching space size or numbers of each element, suitable dispatch energy that is efficient schedule power among components, technical and economic data, system constraints, real discount rate, and inflation rate regarding the economic policy in the region of the project. Therefore, we can use Homer to undertake the simulation, calculation, and seek for optimal system configuration belongs to low investment cost.

\section{Results and Discussion}

The result based on simulation is implemented for different designs of the grid-connected hybrid energy system (PV-FC). Four significant PV tracking techniques briefly named FTSP, HSAT, VSAT and DAT are examined to decide the best alternative techno-economic properties of the system. Furthermore, the operation statue of the optimal design with the best option of PV tracking technology is illustrated. The result is discussed clearly in the following three sections. 


\subsection{Comparison of Various PV Tracking Techniques on the Technical Aspect}

The technical properties of the grid-connected hybrid system (PV-FC) were carefully examined for different PV tracking techniques. The monthly average of PV production is illustrated in Figure 10. It can obviously be seen that both VSAT and FTSP are dominated in terms of achievement of high PV power production. However, VSAT is noticeably superior except in the period April-August. On the other hand, DAT and HSAT come next, and it can be observed that DAT is helped for product high power than HSAT except in the period April-August.

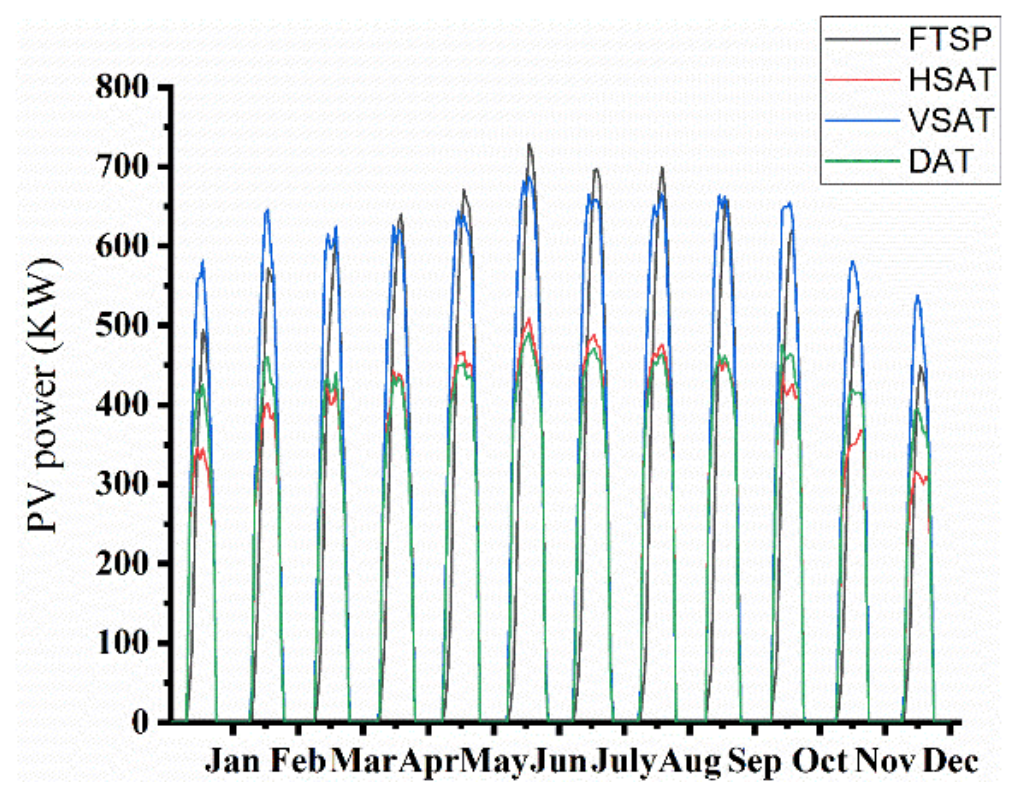

Figure 10. Monthly average-hourly data of PV production for different PV tracking techniques.

In terms of yearly total PV power production, as can be observed in Figure 11a, the VSAT has the highest power generated followed by FTSP, DAT and HSAT corresponded of 2078.265 MWh/year, 1640.007 MWh/year, 1595.342 MWh/year and $1556.716 \mathrm{MWh} /$ year, respectively. In other words, it can be noticed that the VSAT produced $26.7 \%, 30.2 \%$, and $33.5 \%$ more power than FTSP, DAT and HSAT, respectively.

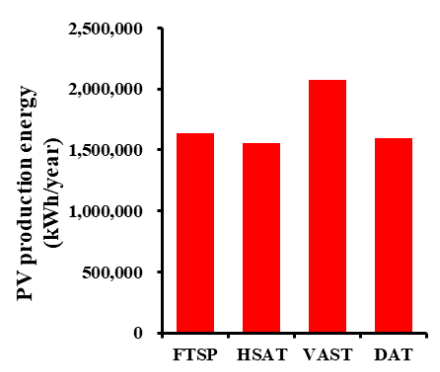

(a)

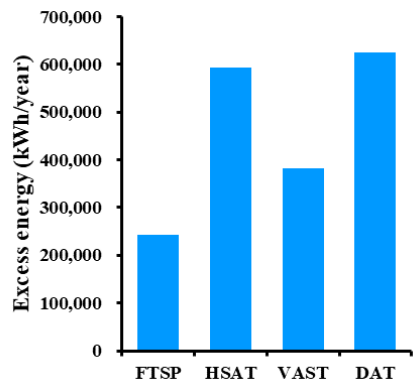

(b)

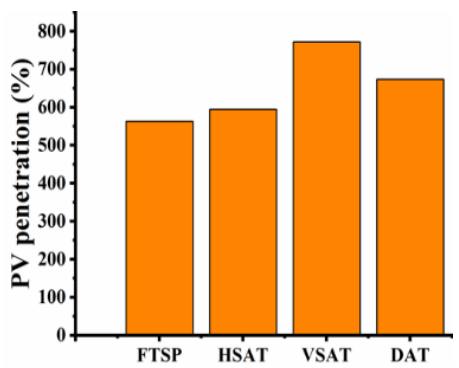

(c)

Figure 11. (a) PV energy production of one year for different PV tracking techniques, (b) excess energy for different PV tracking techniques, (c) PV penetration for different PV tracking techniques.

The excess power occurred in the system due to the production from PV surpassing consumption. In such a microgrid hybrid renewable power system the excess power is usually dumped or can be utilized for further application. However, in this study the excess power will be injected back to the utility for further revenues. In this model the highest excess energy belongs to the DAT technique 
and corresponded to $625.451 \mathrm{MWh} /$ year, the HSAT, VSAT, and FTSP are ranked sequentially next, and corresponded to $592.921 \mathrm{MWh} /$ year, $381.284 \mathrm{MWh} /$ year, and $243.546 \mathrm{MWh} /$ year, respectively, which can be depicted in Figure 11b. PV penetration is an important criterion taken into account for discussing this. It is defined as the ration of peak PV power to the peak load, here in grid-connected hybrid system (PV/FC), the maximum PV penetration is given by VSAT which was $772 \%$, followed by DAT, HSAT, and FTSP corresponding to $674 \%, 595 \%$ and $563 \%$, respectively, as can be seen in Figure 11c. In other words, $209 \%$ is the difference between the highest value belonged to the VSAT and the lowest belonged to the FTSP, and between them, the significant role of the PV tracking techniques for increasing PV energy penetration to the grid can additionally be noticed.

Additionally, it is more interesting to discuss the energy purchased and sold from and to the grid for each month, taking into account four considered PV tracking techniques. The Figure 12a shows the monthly average energy purchased from the grid, the curves demonstrated that DAT, and HSAT achieved the highest energy purchases in the calendar year, followed by FTSP and VSAT, respectively. It can also be seen that the highest purchased energy is in the summer, where the high load demand reported in this period, as discussed early in Section 3.3. To clearly distinguish, the yearly total energy purchasing is explicitly depicted in Figure $12 \mathrm{~b}$. The figure shows that the DAT is given the yearly highest purchased energy estimated at $402.087 \mathrm{MWh} /$ year followed by HSAT, FTSP, and VSAT corresponded of 401.295 MWh/year, 289.038 MWh/year, and 258.016 MWh/year, respectively.

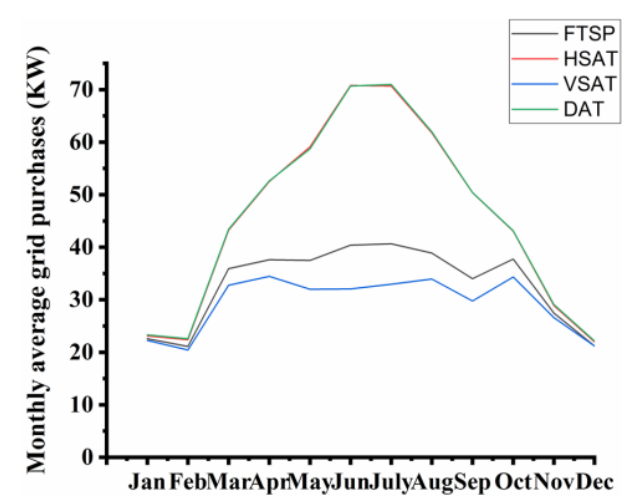

(a)

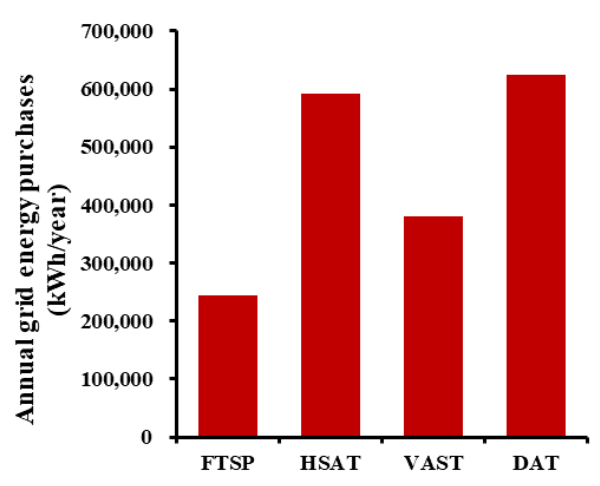

(b)

Figure 12. (a) Monthly average energy purchased from the grid for different PV tracking techniques, (b) accumulatively annual energy purchased from the grid for different PV tracking techniques.

On the other hand, the monthly average sold to the grid is illustrated in Figure 13a. It can be seen that VSAT obtains the highest monthly average energy sold back to the grid. FTSP comes next, and where both HSAT and DAT have demonstrated the lowest sold energy, there was little difference that can be noted in terms of annually total sold energy. Additionally, it was noticed that, the lowest sold energy in the summer, where the load energy was high demand at this period. In terms of yearly total energy sold back to the grid, the VSAT is sold $561.280 \mathrm{MWh} /$ year annual energy, and FTSP, HSAT, and DAT are ranked next corresponding to $321.537 \mathrm{MWh} /$ year, $37.115 \mathrm{MWh} /$ year, and $36.470 \mathrm{MWh} /$ year, respectively. As shown in Figure 13b. 


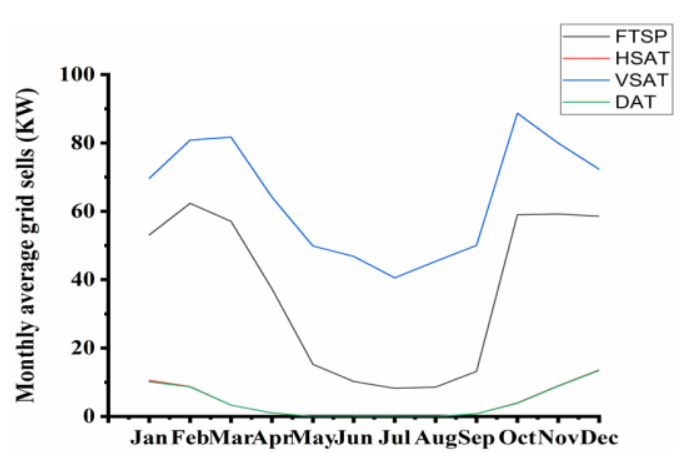

(a)

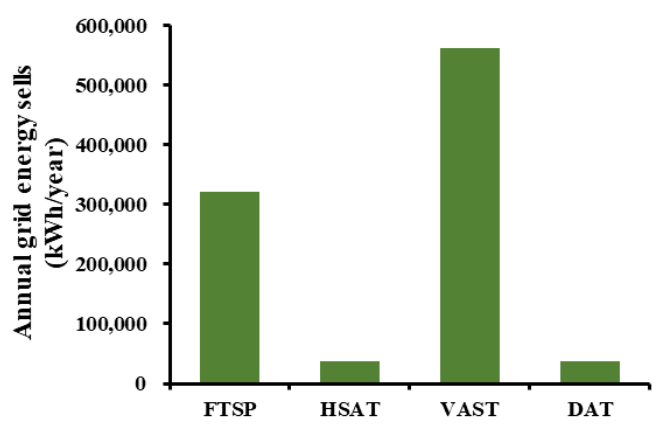

(b)

Figure 13. (a) Monthly average energy sold to the grid for different PV tracking techniques, (b) Accumulative annual energy sold to the grid for different PV tracking techniques.

Saudi Arabia is the 2nd largest oil producer in the world, the basic source of electricity generation is fossil fuel. It causes major environmental concerns, as literature reported that Saudi Arabia participated with $2.8 \%$ of global emission and $56.34 \%$ of internal $\mathrm{CO}_{2}$ emission because it was more reliant on oil for electricity generation and heating production. Which pushed Saudi Arabia to make strategic to install 41 GW of solar energy by the time of 2032, with the total cost 108.9 billion [79]. In this context, a PV tracker can play a vital role to capture solar irradiation as much as possible and help to increase PV productivity, PV penetration, and lead to minimize reliance on the grid that can reduce $\mathrm{CO}_{2}$ emission. This is discussed and proved in our study for all selected PV tracker design.

Figure 14 illustrates that VSAT is achieved the lowest $\mathrm{CO}_{2}$ emission, followed by FTSP, HSAT, and DAT with corresponding values of 255,432 kg/year, 286,144 kg/year, 397,279 kg/year, and $398,063 \mathrm{~kg} /$ year, respectively. The reason is that the VSAT technology helps purchase the lowest energy from the grid and sell the highest energy as discussed earlier in Figures 12b and 13b. The discussion of the technical properties of grid-connected hybrid energy system (PV-FC) for the four major PV tracking techniques highlight that the vertical single axis tracker (VSAT) is the best option for grid-connected hybrid energy system (PV-FC) in the location of this study.

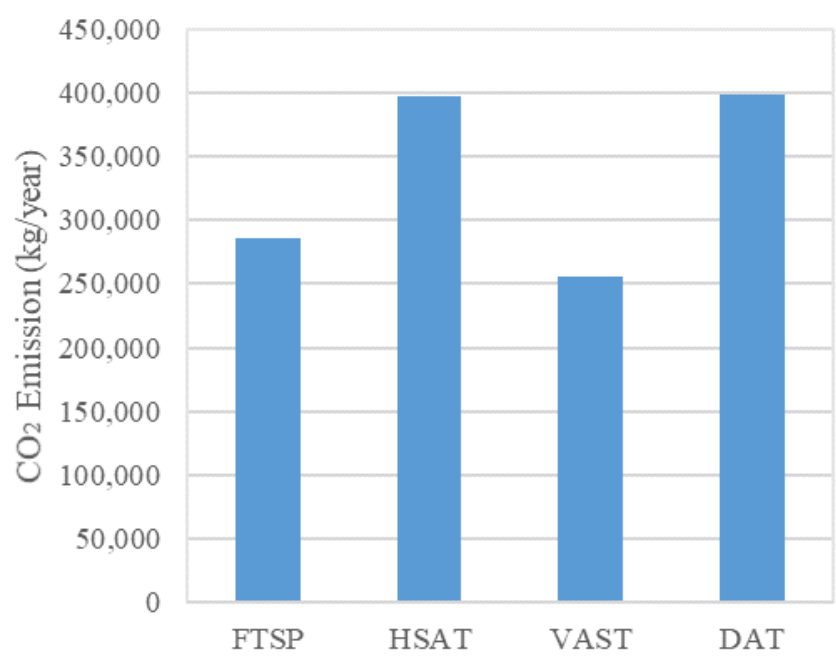

Figure 14. $\mathrm{CO}_{2}$ emission for different PV tracking techniques.

\subsection{Comparison of Various PV Tracking Techniques on the Economic Aspect}

Homer is calculated NPC, LCOE based on Equations (2) and (5). The various design of a grid-connected hybrid energy systems (PV-FC) under the influence of four major PV tracking techniques demonstrate several investment costs options. As shown in Figure 15a, the lowest NPC, LCOE are found 
under the effect of VSAT technology which corresponded to 3,441,850\$, $0.1543 \$ / \mathrm{kWh}$, respectively. The HSAT is ranked 2nd in terms of NPC and 3rd regarding LCOE which corresponded to 3,800,309\$, $0.2739 \$ / \mathrm{kWh}$, respectively. The FTSP is ranked 3rd in terms of NPC and 2nd regarding LCOE which obtained 3,918,589\$, $0.2124 \$ / \mathrm{kWh}$, respectively. The DAT comes last given the highest NPC, LOCE which appreciated $3990264 \$, 0.2878 \$ / \mathrm{kWh}$, respectively.

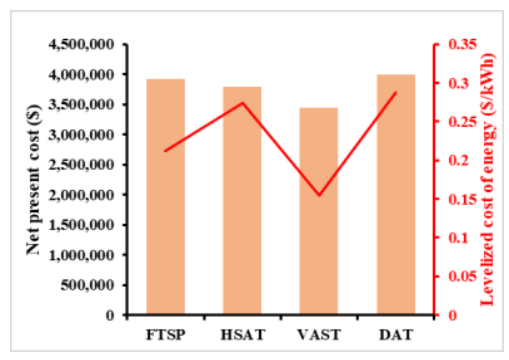

(a)

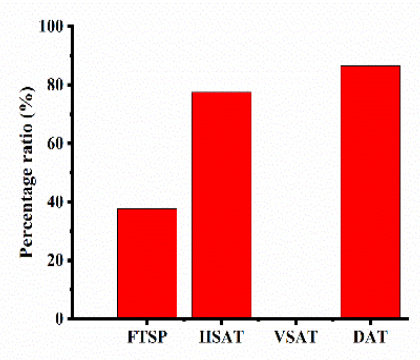

(b)

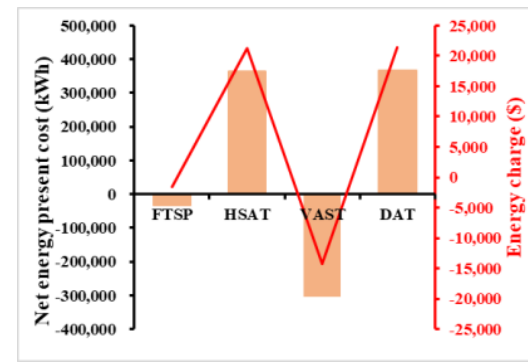

(c)

Figure 15. (a) Net present cost (NPC) and levelized cost of energy (LCOE) for different PV tracking techniques, (b) the difference of LCOE of various PV tracker related to vertical single-axis tracker (VSAT) as base case, (c) Net energy purchases and energy charge for different PV tracker.

With VSAT taken as base case achieving the lowest LCOE, it was compared with the LCOE of other PV tracker in percentage rate, as illustrated in Figure 15b. The figure demonstrated that the VSAT can decline $37.65 \%, 77.5 \%$, and $86.5 \%$, of LCOE than FSAT, HSAT, DAT, respectively. According to the energy flowing from and to the grid which are reported early in Figures 12a and 13a, the net purchased energy which is defined as purchased energy minus sold energy. If the net purchased energy is minus, it means the sold energy is more than is purchased and vice versa. On the other hand, the energy charge is the fees charged to deliver the electricity from and to the grid, if the value is minus, it means the fees of sold energy are more than the fees of purchased power.

Through estimations of net purchased energy for various PV tracking technology, it can significantly notice which PV tracker achieved more revenues that were the reason for reduced LCOE. Through one-year net purchased energy estimation for various PV tracking technology, the highest revenues obtained by VSAT represented to -303.264 MWh net purchased energy corresponded $-14237.8 \$$ energy charge based on tariff policy which has been discussed early in section (2.2.7), followed by FSAT technology for which the net purchased energy was -32.499 MWh corresponding to $-1506.16 \$$ energy charge. And HSAT is coming next, where appreciated net purchased energy $364.180 \mathrm{MWh}$ corresponded to $21297.11 \$$ energy charge. In addition, DAT is ranked last, where obtained 365.617 MWh that is the highest net purchased energy corresponded to 21377.66\$ energy charge.

As illustrated in Figure 15c, it can obviously be seen that the system is more reliable on the grid for DAT and HSAT, respectively. There is a small difference, the reason for which is the low contribution of renewable energy to the system as previously discussed in Figure 11a, that is risen LCOE. Whereas, the designed system sold more energy than purchased for the VSAT and FTSP, respectively. With significant difference noticed, the main reason is that these two designs contributed more in terms of renewable energy production that led to a decline LCOE. The discussion above showed that vertical single axis tracker(VSAT) has superior economic feasibility for the proposed grid-connected hybrid energy system (PV-FC) based on meteorological data and geographical properties of the specific location.

\subsection{Operation Status of the Optimal Grid-Connected Hybrid Energy System (PV-FC) with the Best PV Tracking Technique}

This section discusses the detailed operation status of the optimal design grid-connected hybrid energy system (PV-FC) for selected vertical single axis tracker(VSAT), which has been considered 
as the best PV tracker regarding the techno-economic properties of the system. The optimal size is found at $931 \mathrm{~kW} \mathrm{PV}$ power, $300 \mathrm{~kW}$ electrolyzer power, $100 \mathrm{~kg}$ hydrogen tank capacity, $100 \mathrm{~kW} \mathrm{FC}$ power, $150 \mathrm{~kW}$ grid power, and $363 \mathrm{~kW}$ inverter power. The PV, FC, and grid are supplemented with each other and provide sufficient power to the load with $0.0281 \%$ unmet electric load, $0.0986 \%$ shortage capacity.

The hourly data of PV power generation, electrolyzer input power, FC power, grid power, and load served power are presented in Figure 16 for seven random days of June. The figure shows that, the PV, FC, and grid power can meet the demand of the load. Furthermore, PV generates more than the demand of load, inputs extra power into electrolyzer for hydrogen production, and possibly sells back to the grid when it is more than the needs of hydrogen production. Additionally, it can be seen that FC operates for a short period to face critical demand at which the load power was more than grid power.

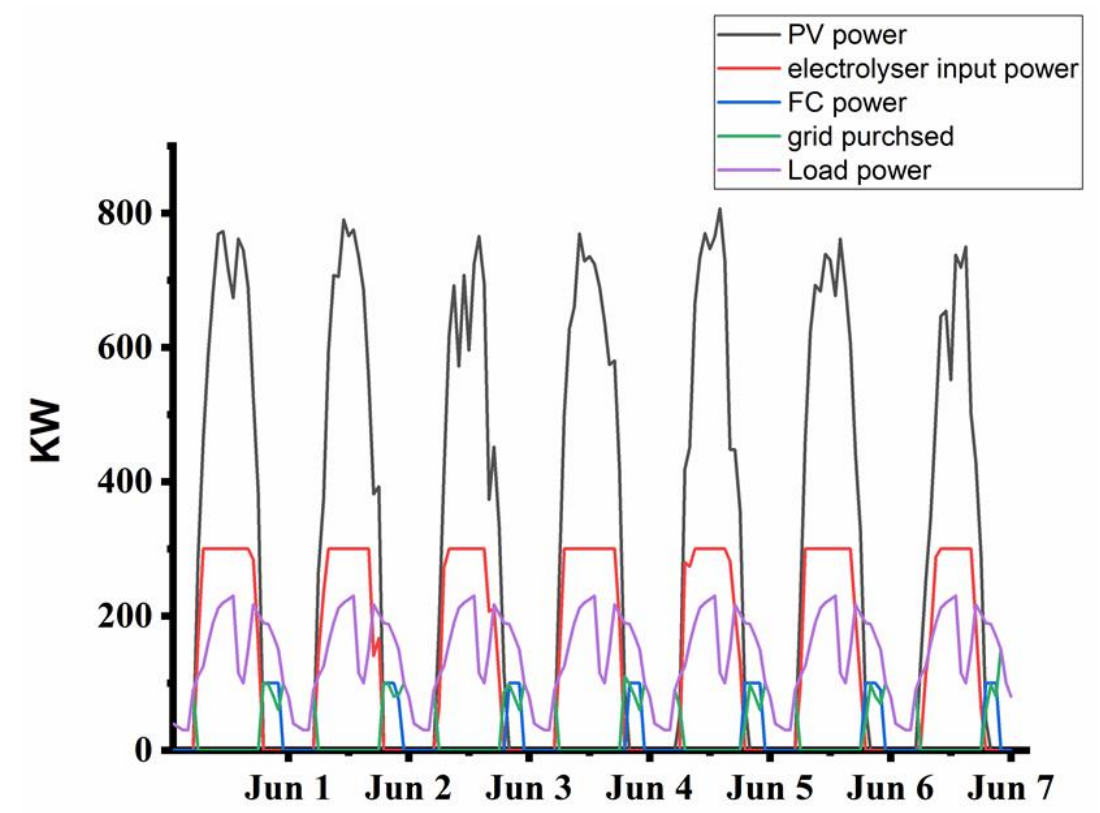

Figure 16. PV power, electrolyzer input power, FC power, grid purchased, and load power at seven days of June using VSAT.

The energy generated by the PV section was $2078.265 \mathrm{MWh} /$ year, which accounted for $87.1 \%$ of total energy generation. Grid produced $258.016 \mathrm{MWh} /$ year, presented $10.8 \%$ of total energy generation, and FC generated $50.066 \mathrm{MWh} /$ year with $2.1 \%$ of total generation. The monthly energy generation from the PV, FC, and grid is illustrated in Figure 17. The figure shows that the major contribution of production comes from the PV system, where the lowest energy produced was recorded in January/December, which was approximately $140 \mathrm{MWh}$ and maximum in June, which was around $200 \mathrm{MWh}$. The FC operated in the summer season from April-September, due to the load power was high in summer and over grid capacity. Therefore, FC based back up power generation operates to assist the grid to meet critical demand. 


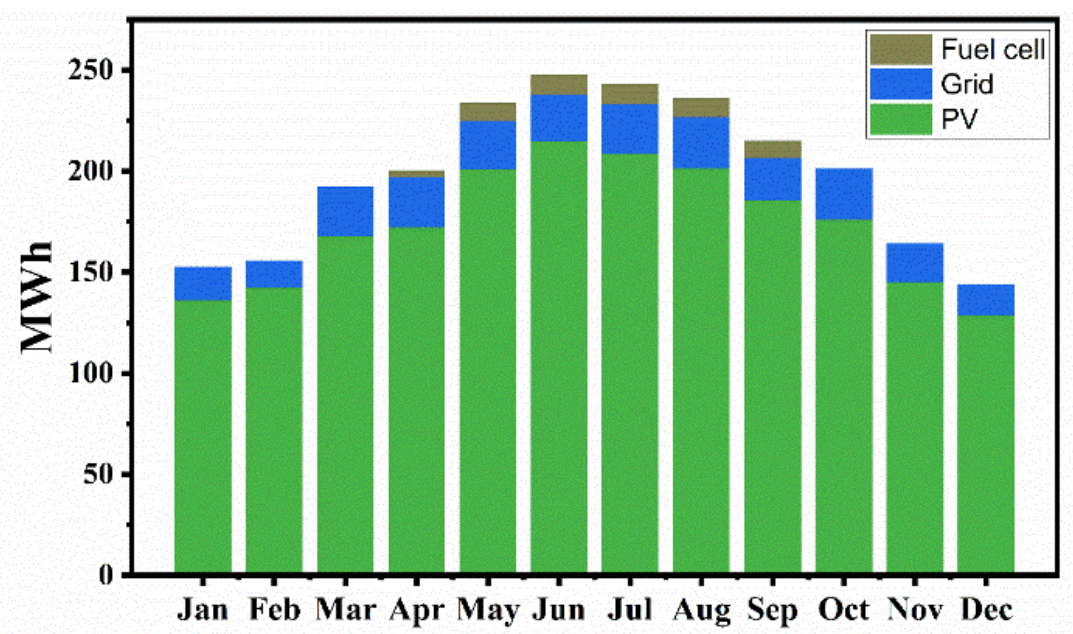

Figure 17. Monthly energy generation of PV, FC, and grid used VSAT.

The PV-based power generation is operated $4378 \mathrm{~h}$ per year during daylight with longer in the summer than winter and peak power output appeared around noon, as can be noticed from Figure 18. The electrolyzer operated $1992 \mathrm{~h}$ per year longer during the daylight in summer than in winter, where the PV produced peak output power, as shown in Figure 19. The FC behaves as backup power generation, it operates $535 \mathrm{~h}$ per year during early night in summer season to face emergency demand power, where the grid could not provide. As illustrated in Figure 20.

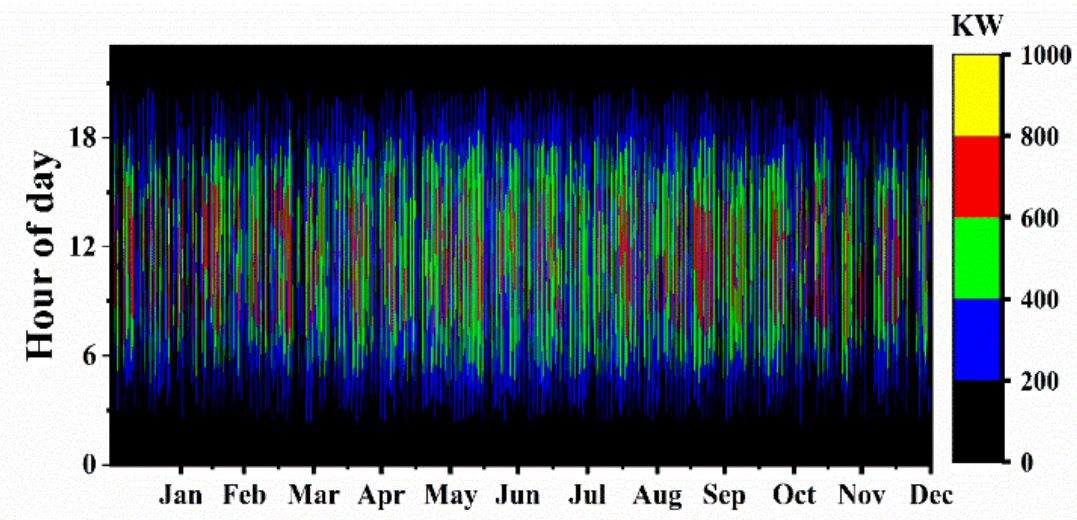

Figure 18. Daily data through the year of PV power output used VSAT.

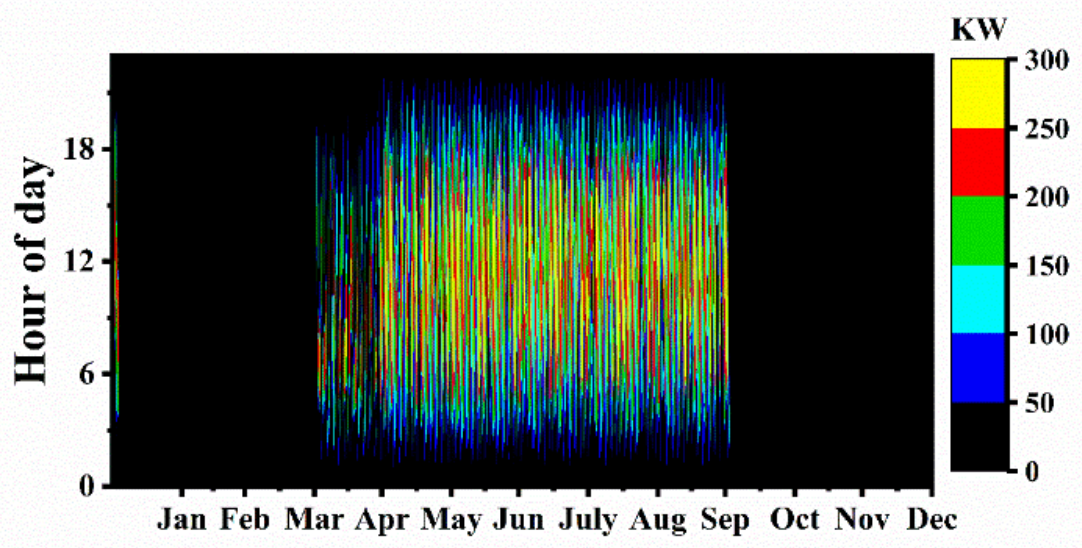

Figure 19. Daily data through the year of electrolyzer input power used VSAT. 


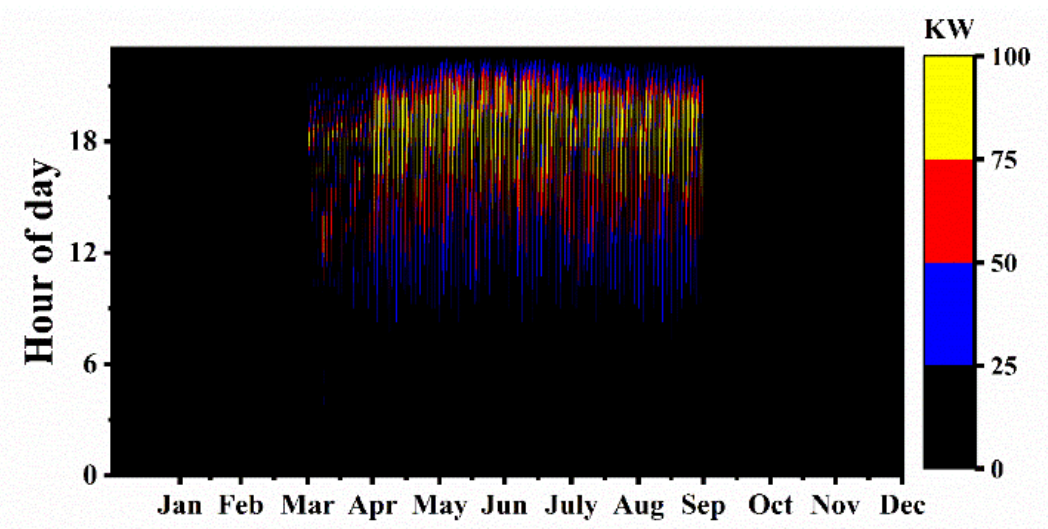

Figure 20. Daily data through the year of FC power used VSAT.

The grid is the main source of power generation. It provides power to the system at day night with maximum rate, in the summer than in the winter. Moreover, the hybrid system (PV-FC) sells back power to the grid during daylight with the maximum rate in the winter than in the summer, due to the high load power in summer season. The D map data of power flow from/to the grid is illustrated in Figure 21a,b for energy purchased and sold, respectively.

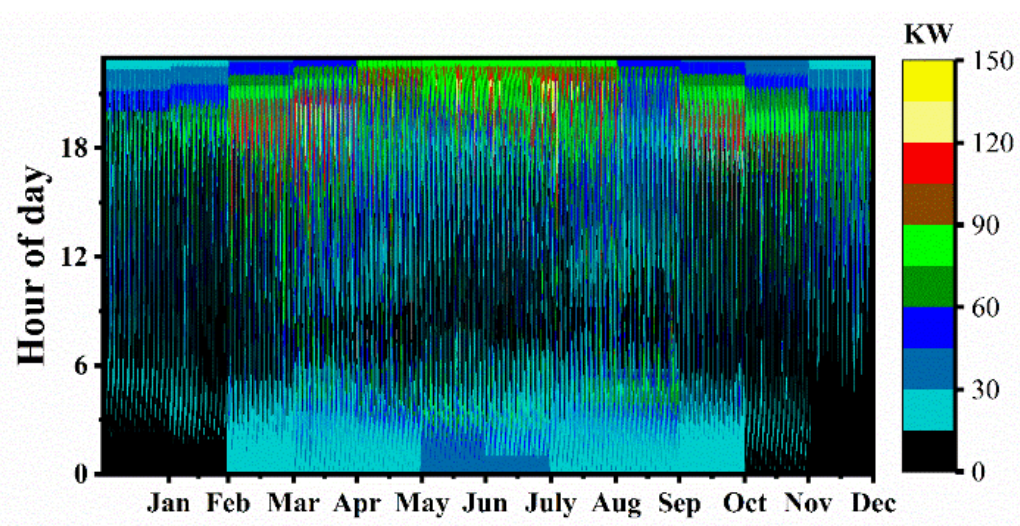

(a)

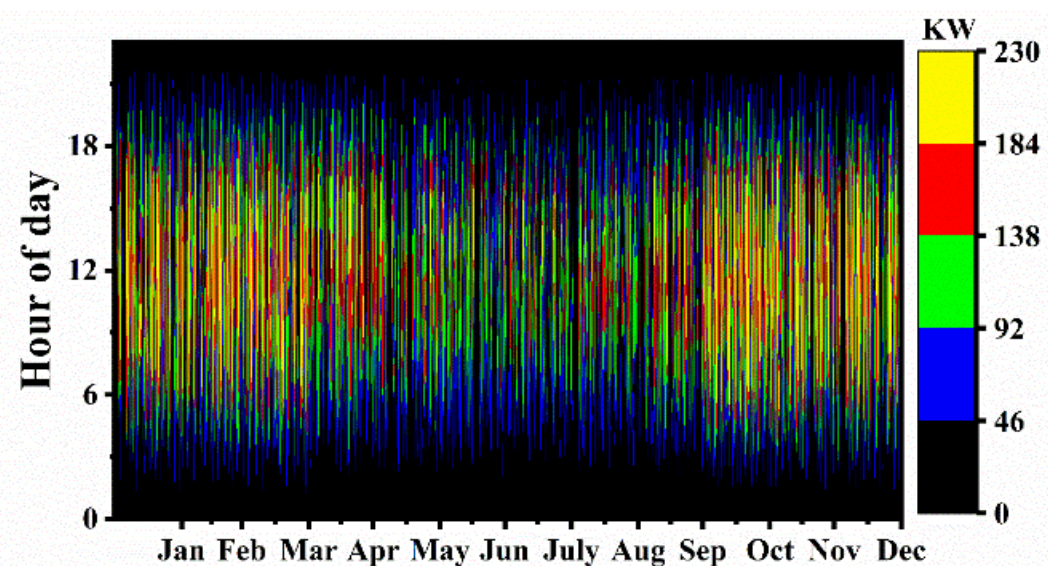

(b)

Figure 21. Daily data through the year of (a) energy purchased (b) energy sold to grid used VSAT. 


\section{Conclusions}

The study was developed to design a grid-connected hybrid power system (PV-FC), and discuss the influence of the major four PV tracking techniques on technical and economic performance of the system. The significant PV tracking techniques included FTSP, HSAT, VSAT, and DAT were considered. Homer Pro was used to perform simulation, calculation, and optimization. Input data such as meteorological condition (solar irradiation and ambient temperature), real agriculture load were considered in Alkharj city, Saudi Arabia. Furthermore, technical and economic data of the system's components came from manufactures. The PV tracking techniques were examined in terms of their influence on techno-economic performance of the proposed system, and the results were assessed and compared in depth. In addition, the optimal design is recommended as the best option for case study. The study found the following key points:

(1) In terms of yearly energy production, the result found that the VSAT was superior in production of the highest power, following by FTSP, DAT and HSAT, respectively.

(2) In terms of PV penetration, the result demonstrates that VSAT recorded $772 \%$ higher PV penetration of solar energy to the grid, followed by DAT, HSAT, and FTSP, which recorded $674 \%$, $595 \%$, and $563 \%$, respectively.

(3) In terms of net purchased energy, VSAT showed the highest of energy sold to the grid than others. Taking the VSAT as the base case that achieved the lowest LCOE, the VSAT can decline $37.65 \%$, $77.5 \%$, and $86.5 \%$ of LCOE than FTSP, HSAT, and DAT, respectively.

(4) The VSAT showed the lowest $\mathrm{CO}_{2}$ emission, while DAT presented the highest $\mathrm{CO}_{2}$ emission. Due to this it was more reliant on the grid. In this context, VSAT can be the lowest environmental effect.

(5) The study deduced the vital role of VSAT that optimizes the technical performances and extends to a reduced economic cost of the proposed system. Therefore, VSAT can be highly recommended as the best choice of a grid-connected hybrid (PV-FC) energy system for Alkharj city, Saudi Arabia. The proposed system design method and PV tracker investigation are validated for any location in the world, although the result will be different based on components costs, metrological data.

Author Contributions: Conceptualization: S.M., D.Z. and Y.Z.; Methodology: S.M., D.Z.; Software: S.M.; Validation: S.M.; Formal analysis: S.M.; Investigation: S.M., D.Z., L.W., R.Y. and J.W.; Resources: S.M., Y.Z. and M.L.; Data Curation: S.M., D.Z.; Writing-Original Draft: S.M., D.Z.; Writing-Review and Editing: S.M., D.Z., Y.C., J.L., L.W., R.Y., J.W., Y.Z. and M.L.; Visualization: S.M., D.Z.; Supervision: Y.Z. and M.L.; Project administration: Y.Z. and M.L.; Funding acquisition: Y.Z. and M.L. All authors have read and agreed to the published version of the manuscript.

Funding: This research was funded by National Natural Science Foundation of China (Grant nos. 71974055). This work is supported partially by Natural Science Foundation of Beijing Municipality (L172036), National Natural Science Foundation of China (Grant nos. 51772096), Beijing Science and Technology Project (Z181100005118002), Joint Funds of the Equipment Pre-Research and Ministry of Education(6141A020225), Par-Eu Scholars Program, Science and Technology Beijing 100 Leading Talent Training Project, the Fundamental Research Funds for the Central Universities (2017ZZD02) and the NCEPU “Double First-Class" Program.

Conflicts of Interest: The authors declare no conflict of interest.

\begin{tabular}{ll}
\multicolumn{2}{l}{ Abbreviations } \\
PV & Photovoltaic \\
FC & Fuel cell \\
NPC & Net present cost \\
LCOE & Levelized cost of energy \\
IEA & International energy agency \\
COE & Cost of energy \\
GHG & Greenhouse gas \\
DC & Direct current
\end{tabular}




$\begin{array}{ll}\text { AC } & \text { Alternative current } \\ \text { FTSP } & \text { Fixed-tilt solar panel } \\ \text { HSAT } & \text { Horizontal single-axis tracker } \\ \text { VSAT } & \text { Vertical single-axis tracker } \\ \text { DAT } & \text { Dual-axis tracker } \\ \text { O\&M } & \text { Operation and maintenance } \\ \text { PEM } & \text { Proton exchange membrane } \\ \text { REFIT } & \text { Renewable energy feed in tariff } \\ \text { GHI } & \text { Global horizontal irradiance }\end{array}$

\section{References}

1. Fossil Fuel. Available online: https://www.studentenergy.org/topics/fossil-fuels?gclid= Cj0KCQiAovfvBRCRARIsADEmbRJcgjWyvt8jZoT53xX8_OspJZKWfA4-t2X5jqRdyKsVpOc4EDL_ _bgaAv_PEALw_wcB (accessed on 27 November 2020).

2. Ambrose, J. "Renewable Energy to Expand by 50\% in Next Five Years-Report," Support the Guardian. Available online: https://www.theguardian.com/environment/2019/oct/21/renewable-energy-to-expand-by50-in-next-five-years-report (accessed on 27 November 2020).

3. Chiang, P.-H.; Chiluvuri, S.P.V.; Dey, S.; Nguyen, T.Q. Forecasting of Solar Photovoltaic System Power Generation Using Wavelet Decomposition and Bias-Compensated Random Forest. In Proceedings of the 9th IEEE Green Technology Conference, Denver, CO, USA, 29-31 March 2017; pp. 260-266.

4. Velloso, M.F.A.; Martins, F.R.; Pereira, E.B. Case study for hybrid power generation combining hydro- and photovoltaic energy resources in the Brazilian semiarid region. Clean Technol. Environ. Policy 2019, 21, 941-952.

5. Indragandhi, V.; Subramaniyaswamy, V.; Logesh, R. Resources, configurations, and soft computing techniques for power management and control of PV/wind hybrid system. Renew. Sustain. Energy Rev. 2017, 69, 129-143.

6. Notton, G.; Nivet, M.-L.; Voyant, C.; Paoli, C.; Darras, C.; Motte, F.; Fouilloy, A. Intermittent and stochastic character of renewable energy sources: Consequences, cost of intermittence and benefit of forecasting. Renew. Sustain. Energy Rev. 2018, 87, 96-105. [CrossRef]

7. Nadjemi, O.; Nacer, T.; Hamidat, A.; Salhi, H. Optimal hybrid PV/wind energy system sizing: Application of cuckoo search algorithm for Algerian dairy farms. Renew. Sustain. Energy Rev. 2017, 70, 1352-1365. [CrossRef]

8. Mohod, S.B.; Parihar, V.; Nimkar, S.D. Hybrid power system with integration of wind, battery and solar PV system. In Proceedings of the 2017 IEEE International Conference on Power, Control, Signals and Instrumentation Engineering (ICPCSI), Chennai, India, 21-22 September 2017; pp. 2332-2337.

9. Li, F.-F.; Qiu, J. Multi-objective optimization for integrated hydro-photovoltaic power system. Appl. Energy 2016, 167, 377-384. [CrossRef]

10. Bierling, P. The potential of hybrid floating pv-hydropower plants in Vietnam an energy justice perspective. Master's Thesis, Eindhoven University of Technology, Eindhoven, The Netherlands, 11 August 2019.

11. Shivashankar, S.; Mekhilef, S.; Mokhlis, H.; Karimi, M. Mitigating methods of power fluctuation of photovoltaic (PV) sources-A review. Renew. Sustain. Energy Rev. 2016, 59, 1170-1184. [CrossRef]

12. Li, C.; Zhou, D.; Zheng, Y. Techno-economic comparative study of grid-connected PV power systems in five climate zones, China. Energy 2018, 165, 1352-1369. [CrossRef]

13. Ramli, M.A.; Hiendro, A.; Sedraoui, K.; Twaha, S. Optimal sizing of grid-connected photovoltaic energy system in Saudi Arabia. Renew. Energy 2015, 75, 489-495.

14. Al Garni, H.Z.; Awasthi, A.; Ramli, M.A.M. Optimal design and analysis of grid-connected photovoltaic under different tracking systems using HOMER. Energy Convers. Manag. 2018, 155, 42-57. [CrossRef]

15. Aktas, A.; Erhan, K.; Ozdemir, S.; Özdemir, E. Experimental investigation of a new smart energy management algorithm for a hybrid energy storage system in smart grid applications. Electr. Power Syst. Res. 2017, 144, 185-196. [CrossRef]

16. Dong, W.; Li, Y.; Xiang, J. Optimal Sizing of a Stand-Alone Hybrid Power System Based on Battery/Hydrogen with an Improved Ant Colony Optimization. Energies 2016, 9, 785. [CrossRef] 
17. Fan, X.-C.; Wang, W.-Q.; Shi, R.-J.; Cheng, Z.-J. Hybrid pluripotent coupling system with wind and photovoltaic-hydrogen energy storage and the coal chemical industry in Hami, Xinjiang. Renew. Sustain. Energy Rev. 2017, 72, 950-960. [CrossRef]

18. Jing, W.; Lai, C.H.; Wong, W.S.; Wong, M.D. A comprehensive study of battery-supercapacitor hybrid energy storage system for standalone PV power system in rural electrification. Appl. Energy 2018, 224, 340-356. [CrossRef]

19. Amrouche, S.O.; Rekioua, D.; Bacha, S. Overview of energy storage in renewable energy systems. Int. J. Hydrog. Energy 2016, 41, 20914-20927. [CrossRef]

20. Das, H.S.; Dey, A.; Wei, T.C.; Yatim, A.H.M. Feasibility analysis of standalone PV/wind/battery hybrid energy system for rural Bangladesh. Int. J. Renew. Energy Res. 2016, 6, 402-412.

21. Hossain, M.; Mekhilef, S.; Olatomiwa, L. Performance evaluation of a stand-alone PV-wind-diesel-battery hybrid system feasible for a large resort center in South China Sea, Malaysia. Sustain. Cities Soc. 2017, 28, 358-366. [CrossRef]

22. Roumila, Z.; Rekioua, D.; Rekioua, T. Energy management based fuzzy logic controller of hybrid system wind/photovoltaic/diesel with storage battery. Int. J. Hydrog. Energy 2017, 42, 19525-19535. [CrossRef]

23. Qian, J.; Jing, X. Wind-driven hybridized triboelectric-electromagnetic nanogenerator and solar cell as a sustainable power unit for self-powered natural disaster monitoring sensor networks. Nano Energy 2018, 52, 78-87. [CrossRef]

24. Ayodele, T.; Ogunjuyigbe, A. Mitigation of wind power intermittency: Storage technology approach. Renew. Sustain. Energy Rev. 2015, 44, 447-456. [CrossRef]

25. Gao, D.; Jiang, D.; Liu, P.; Li, Z.; Hu, S.; Xu, H. An integrated energy storage system based on hydrogen storage: Process configuration and case studies with wind power. Energy 2014, 66, 332-341. [CrossRef]

26. Tabanjat, A.; Becherif, M.; Hissel, D.; Ramadan, H. Energy management hypothesis for hybrid power system of $\mathrm{H} 2$ /WT/PV/GMT via AI techniques. Int. J. Hydrog. Energy 2018, 43, 3527-3541. [CrossRef]

27. Maleki, A. Design and optimization of autonomous solar-wind-reverse osmosis desalination systems coupling battery and hydrogen energy storage by an improved bee algorithm. Desalination 2018, 435, $221-234$. [CrossRef]

28. Mohammed, O.H.; Amirat, Y.; Benbouzid, M.; Elbaset, A.A.; Elbaset, A.A. Optimal design of a PV/fuel cell hybrid power system for the city of Brest in France. In Proceedings of the 2014 1st International Conference on Green Energy (ICGE), Sfax, Tunisia, 25-27 March 2014; pp. 119-123.

29. Ghenai, C.; Salameh, T.; Merabet, A. Technico-economic analysis of off grid solar PV/Fuel cell energy system for residential community in desert region. Int. J. Hydrog. Energy 2020, 45, 11460-11470. [CrossRef]

30. Birol, F. How Hydrogen Can Offer a Clean Energy Future, World Economic Forum. Available online: https://www.weforum.org/agenda/2019/06/how-hydrogen-can-offer-a-clean-energy-future (accessed on 27 November 2020).

31. Fuel Cell. National Geographic. 2019. Available online: https://www.nationalgeographic.com/environment/ global-warming/fuel-cells/ (accessed on 27 November 2020).

32. Staffell, I.; Scamman, D.; Abad, A.V.; Balcombe, P.; Dodds, P.E.; Ekins, P.; Shah, N.; Ward, K.R. The role of hydrogen and fuel cells in the global energy system. Energy Environ. Sci. 2019, 12, 463-491. [CrossRef]

33. Barbir, F. PEM Fuel Cells Theory and Practice, 2nd ed.; Elsevier, Inc.: Amsterdam, The Netherlands, 2013.

34. Das, H.S.; Tan, C.W.; Yatim, A.; Lau, K.Y. Feasibility analysis of hybrid photovoltaic/battery/fuel cell energy system for an indigenous residence in East Malaysia. Renew. Sustain. Energy Rev. 2017, 76, 1332-1347. [CrossRef]

35. Samy, M.; Barakat, S.; Ramadan, H. A flower pollination optimization algorithm for an off-grid PV-Fuel cell hybrid renewable system. Int. J. Hydrog. Energy 2019, 44, 2141-2152. [CrossRef]

36. Maleki, A.; Rosen, M.A.; Pourfayaz, F. Optimal Operation of a Grid-Connected Hybrid Renewable Energy System for Residential Applications. Sustainability 2017, 9, 1314. [CrossRef]

37. Cordiner, S.; Mulone, V.; Giordani, A.; Savino, M.; Tomarchio, G.; Malkow, T.; Tsotridis, G.; Pilenga, A.; Karlsen, M.; Jensen, J. Fuel cell based Hybrid Renewable Energy Systems for off-grid telecom stations: Data analysis from on field demonstration tests. Appl. Energy 2017, 192, 508-518. [CrossRef]

38. Hatata, A.; Lafi, A. Clonal Selection Algorithm for Optimum Sizing of WT/PV/FC Hybrid Renewable Power System. In Proceedings of the 1st International Conference on Computer Applications \& Information Security (ICCAIS), Riyadh, Saudi Arabia, 4-5 April 2018. 
39. Majidi, M.; Nojavan, S.; Zare, K. Optimal stochastic short-term thermal and electrical operation of fuel cell/photovoltaic/battery/grid hybrid energy system in the presence of demand response program. Energy Convers. Manag. 2017, 144, 132-142. [CrossRef]

40. Al-Sharafi, A.; Sahin, A.Z.; Ayar, T.; Yilbas, B.S. Techno-economic analysis and optimization of solar and wind energy systems for power generation and hydrogen production in Saudi Arabia. Renew. Sustain. Energy Rev. 2017, 69, 33-49. [CrossRef]

41. Duman, A.C.; Güler, Ö. Techno-economic analysis of off-grid PV/wind/fuel cell hybrid system combinations with a comparison of regularly and seasonally occupied households. Sustain. Cities Soc. 2018, 42, 107-126. [CrossRef]

42. Kebede, M.H.; Beyene, G.B. Feasibility Study of PV-Wind-Fuel Cell Hybrid Power System for Electrification of a Rural Village in Ethiopia. J. Electr. Comput. Eng. 2018, 2018, 1-9. [CrossRef]

43. Khiareddine, A.; Ben Salah, C.; Rekioua, D.; Mimouni, M.F. Sizing methodology for hybrid photovoltaic /wind/ hydrogen/battery integrated to energy management strategy for pumping system. Energy 2018, 153, 743-762. [CrossRef]

44. Zhang, W.; Maleki, A.; Rosen, M.A.; Liu, J. Optimization with a simulated annealing algorithm of a hybrid system for renewable energy including battery and hydrogen storage. Energy 2018, 163, 191-207. [CrossRef]

45. Jamalaiah, A.; Raju, C.P.; Srinivasarao, R. Optimization and operation of a renewable energy based pv-fc-micro grid using homer. In Proceedings of the 2017 International Conference on Inventive Communication and Computational Technologies (ICICCT), Coimbatore, India, 10-11 March 2017.

46. Cervantes, I.; Hernandez-Nochebuena, M.; Cano-Castillo, U.; Araujo-Vargas, I. A graphical approach to optimal power management for uncertain OFF-Grid PV-FC-electrolyzer-battery hybrid systems. Int. J. Hydrog. Energy 2018, 43, 19336-19351. [CrossRef]

47. Abadlia, I.; Adjabi, M.; Bouzeria, H. Sliding mode based power control of grid-connected photovoltaic-hydrogen hybrid system. Int. J. Hydrog. Energy 2017, 42, 28171-28182. [CrossRef]

48. Nasri, S.; Ben Slama, S.; Yahyaoui, I.; Zafar, B.; Cherif, A. Autonomous hybrid system and coordinated intelligent management approach in power system operation and control using hydrogen storage. Int. J. Hydrog. Energy 2017, 42, 9511-9523. [CrossRef]

49. Zulkafli, R.S.; Bawazir, A.S.; Amin, N.A.M.; Hashim, M.S.M.; Majid, M.S.A.; Nasir, N.F.M. Dual axis solar tracking system in Perlis, Malaysia. Telecommun. Electron. Comput. Eng. 2018, 10, 91-94.

50. Vieira, R.; Guerra, F.; Vale, M.; Araújo, M. Comparative performance analysis between static solar panels and single-axis tracking system on a hot climate region near to the equator. Renew. Sustain. Energy Rev. 2016, 64, 672-681. [CrossRef]

51. Hu, Y.; Yao, Y. A methodology for calculating photovoltaic field output and effect of solar tracking strategy. Energy Convers. Manag. 2016, 126, 278-289. [CrossRef]

52. Eldin, S.S.; Abd-Elhady, M.; Kandil, H. Feasibility of solar tracking systems for PV panels in hot and cold regions. Renew. Energy 2016, 85, 228-233. [CrossRef]

53. Seme, S.; Štumberger, B.; Hadžiselimović, M. A novel prediction algorithm for solar angles using second derivative of the energy for photovoltaic sun tracking purposes. Sol. Energy 2016, 137, 201-211. [CrossRef]

54. Ruelas, J.; Muñoz, F.; Lucero, B.; Palomares-Ruiz, J. PV Tracking Design Methodology Based on an Orientation Efficiency Chart. Appl. Sci. 2019, 9, 894. [CrossRef]

55. Karpić, J.; Sharma, E.; Khatib, T.; Elmenreich, W. Comparison of solar power measurements in alpine areas using a mobile dual-axis tracking system. Energy Inform. 2019, 2, 1-14. [CrossRef]

56. Shabani, M.; Mahmoudimehr, J. Techno-economic role of PV tracking technology in a hybrid PV-hydroelectric standalone power system. Appl. Energy 2018, 212, 84-108. [CrossRef]

57. Sinha, S.; Chandel, S. Analysis of fixed tilt and sun tracking photovoltaic-micro wind based hybrid power systems. Energy Convers. Manag. 2016, 115, 265-275. [CrossRef]

58. Kumar, N.M.; Vishnupriyan, J.; Sundaramoorthi, P. Techno-economic optimization and real-time comparison of sun tracking photovoltaic system for rural healthcare building. J. Renew. Sustain. Energy 2019, 11, 015301. [CrossRef]

59. Racharla, S.; Rajan, K. Solar tracking system-A review. Int. J. Sustain. Eng. 2017, 10, 72-81.

60. Li, C.; Yu, W. Techno-economic comparative analysis of off-grid hybrid photovoltaic/diesel/battery and photovoltaic/battery power systems for a household in Urumqi, China. J. Clean. Prod. 2016, 124, 258-265. [CrossRef] 
61. Dahiya, D.; Agrawal, R.; Agrawal, D. Performance Analysis Based on Axis Tracking of PV System. Int. Organ. Sci. Res. J. Eng. 2019, 9, 32-39.

62. Jobair, H.K.; Mahdi, J.M. Economic and Environmental Feasibility of Constructing a Grid-Connected Sun-Tracking PV Power Plant in Iraq. Int. J. Renew. Energy Res. 2019, 9, 997-1004.

63. Choi, W.; Pate, M.B.; Warren, R.D.; Nelson, R.M. An economic analysis comparison of stationary and dual-axis tracking grid-connected photovoltaic systems in the US Upper Midwest. Int. J. Sustain. Energy 2017, 37, 455-478. [CrossRef]

64. Alharthi, Y.Z.; Siddiki, M.K.; Chaudhry, G. Resource Assessment and Techno-Economic Analysis of a Grid-Connected Solar PV-Wind Hybrid System for Different Locations in Saudi Arabia. Sustainability 2018, 10, 3690. [CrossRef]

65. Renvu, GCL Solar PV. Available online: https://www.renvu.com/Browse?website=solar\#Solar-Products/ Mono-Poly-Crystalline-Solar-Modules (accessed on 27 November 2020).

66. Rezk, H.; Dousoky, G.M. Technical and economic analysis of different configurations of stand-alone hybrid renewable power systems-A case study. Renew. Sustain. Energy Rev. 2016, 62, 941-953. [CrossRef]

67. Mayyas, A.; Mann, M. Manufacturing Competitiveness Analysis for Hydrogen Refueling Stations. Int. J. Hydrog. Energy 2019, 44, 9121-9142. [CrossRef]

68. Genral Power Technology, Alibaba. Available online: https://gpcpower.en.alibaba.com/?spm=a2700. wholesale.cordpanyb.1.38264feaasWrN3 (accessed on 27 November 2020).

69. Rezk, H.; Sayed, E.T.; Al-Dhaifallah, M.; Obaid, M.; El-Sayed, A.H.M.; Abdelkareem, M.A.; Olabi, A. Fuel cell as an effective energy storage in reverse osmosis desalination plant powered by photovoltaic system. Energy 2019, 175, 423-433. [CrossRef]

70. Trading Economics. Available online: https://tradingeconomics.com/saudi-arabia/interest-rate (accessed on 27 November 2020).

71. Inflation Rate in Saudi Arabia from 1984 to 2024. Available online: https://www.statista.com/statistics/268062/ inflation-in-saudi-arabia/ (accessed on 27 November 2020).

72. Aziz, A.S.; Tajuddin, M.F.N.; Adzman, M.R.; Ramli, M.A.M.; Mekhilef, S. Energy Management and Optimization of a PV/Diesel/Battery Hybrid Energy System Using a Combined Dispatch Strategy. Sustainability 2019, 11, 683. [CrossRef]

73. Kansara, B.U.; Parekh, B.R. Penetration of renewable energy resources based dispatch strategies for isolated hybrid systems. Int. J. Electr. Electron. Eng. Res. 2013, 3, 121-130.

74. Al Kharj, Saudi Arabia Geographic Information. LatLong. Available online: https://www.latlong.net/place/ al-kharj-saudi-arabia-14178.html (accessed on 27 November 2020).

75. Metorological Data Access, NASA Prediction of Worldwide Energy Resources. Available online: https: //power.larc.nasa.gov/ (accessed on 27 November 2020).

76. OFW Talks. Available online: http://ofwtalks.com/ofws-destination-in-saudi-arabia-al-kharj/ (accessed on 27 November 2020).

77. Munir AL-Ali \& Sons Co. Available online: www.masc-jo.com (accessed on 27 November 2020).

78. Qolipour, M.; Mostafaeipour, A.; Tousi, O.M. Techno-economic feasibility of a photovoltaic-wind power plant construction for electric and hydrogen production: A case study. Renew. Sustain. Energy Rev. 2017, 78, 113-123. [CrossRef]

79. Salam, M.A.; Khan, S.A. Transition towards sustainable energy production-A review of the progress for solar energy in Saudi Arabia. Energy Explor. Exploit. 2017, 36, 3-27. [CrossRef]

Publisher's Note: MDPI stays neutral with regard to jurisdictional claims in published maps and institutional affiliations.

(C) 2020 by the authors. Licensee MDPI, Basel, Switzerland. This article is an open access article distributed under the terms and conditions of the Creative Commons Attribution (CC BY) license (http://creativecommons.org/licenses/by/4.0/). 